Chemistry and Physics

Elsevier Editorial system(tm) for Materials

Manuscript Draft

Manuscript Number:

Title: Development of Self-Assembling Sulfonated Graphene Oxide Membranes as a Potential Proton Conductor

Article Type: Full Length Article

Keywords: graphene oxide; sulfonation; PEM fuel cell; membrane; proton conductivity

Corresponding Author: Dr. Saverio Latorrata, Ph.D.

Corresponding Author's Institution: Politecnico di Milano

First Author: Andrea Basso Peressut

Order of Authors: Andrea Basso Peressut; Saverio Latorrata; Paola Gallo Stampino; Giovanni Dotelli

Abstract: A simple method is reported for the preparation of selfassembling sulfonated graphene oxide membranes (SGO-X) to be studied as a potential proton conductor for proton exchange membrane fuel cells (PEMFCS). The effect of three different sulfuric acid-to-Go molar ratios is investigated, the main aim being the identification of an optimal sulfonation interval ensuring a successful trade-off among composition, structural stability and functional properties. ATR-FTIR and EDX spectroscopies, SEM, thermogravimetry and static contact angle measurements allow to analyze the efficacy of the functionalization of graphene oxide (GO) with sulfonic acid groups (-SO3H) and the uniformity of the component's structure. A preliminary examination of the proton conductivity is performed on the most promising samples (SGO-1, SGO-20) by means of electrochemical impedance spectroscopy (EIS), together with the evaluation of water uptake, ion exchange capacity and degree of sulfonation. This introductory work demonstrates that the proposed SGO-X membranes exhibit notable water-retaining and proton-exchanging properties at elevated temperatures and reduced humidity, compared to pristine GO and Nafion® 212 benchmark specimens. Therefore, these innovative self-standing materials are proved to be worthy of additional studies for the optimization of their features, foreseeing the assessment of their behavior as a possible electrolyte in a PEM fuel cell. 


\title{
Development of Self-Assembling Sulfonated Graphene Oxide Membranes as a Potential Proton Conductor
}
e-mail addresses: andreastefano.basso@polimi.it saverio.latorrata@polimi.it paola.gallo@polimi.it giovanni.dotelli@polimi.it

Andrea Basso Peressut ${ }^{\mathrm{a}}$, Saverio Latorrata ${ }^{\mathrm{a},{ }^{*}, \text { Paola Gallo Stampino }}{ }^{\mathrm{a}}$ and Giovanni Dotelli ${ }^{\mathrm{a}}$

${ }^{\text {a} P o l i t e c n i c o ~ d i ~ M i l a n o, ~ D e p a r t m e n t ~ o f ~ C h e m i s t r y, ~ M a t e r i a l s ~ a n d ~ C h e m i c a l ~ E n g i n e e r i n g ~ " G i u l i o ~ N a t t a ”, ~}$ Piazza Leonardo da Vinci 32, 20133 Milano, Italy

*Corresponding author: Saverio Latorrata, Ph.D.

e-mail address: saverio.latorrata@polimi.it

Phone: (IT) +39 0223993190

Fax: (IT) +3902 23993280 


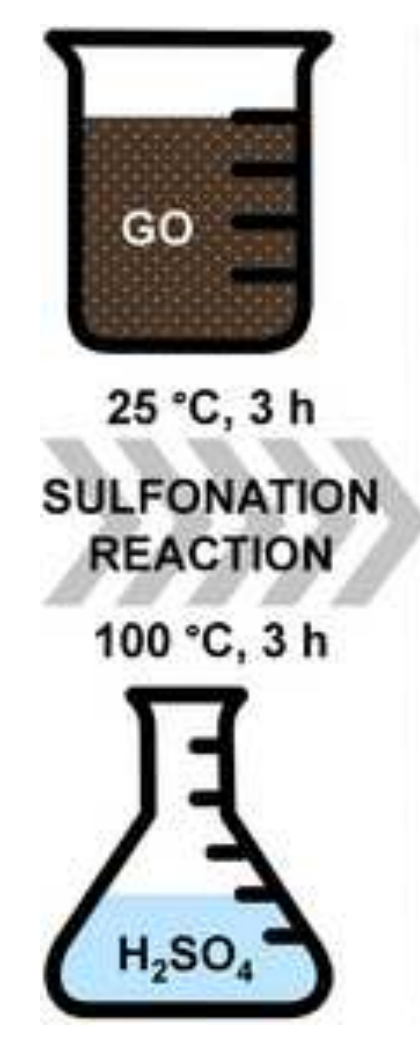

$25^{\circ} \mathrm{C}, 3 \mathrm{~h}$

SULFONATION

REACTION

$100^{\circ} \mathrm{C}, 3 \mathrm{~h}$

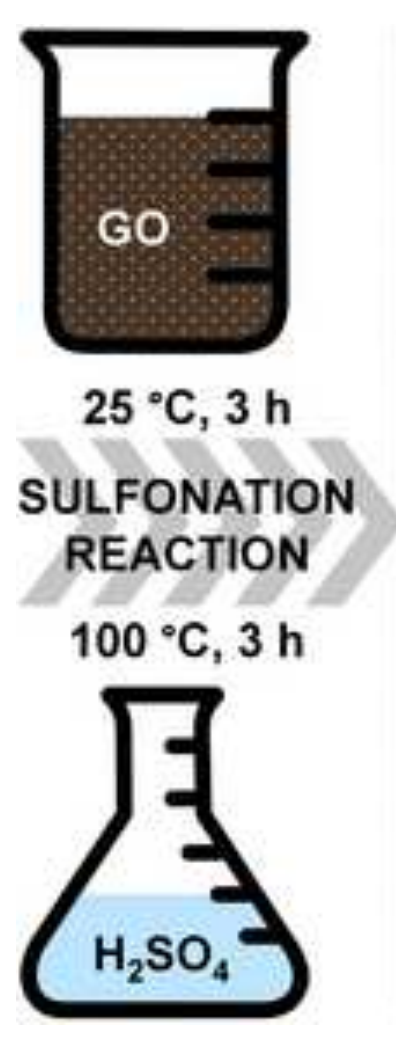

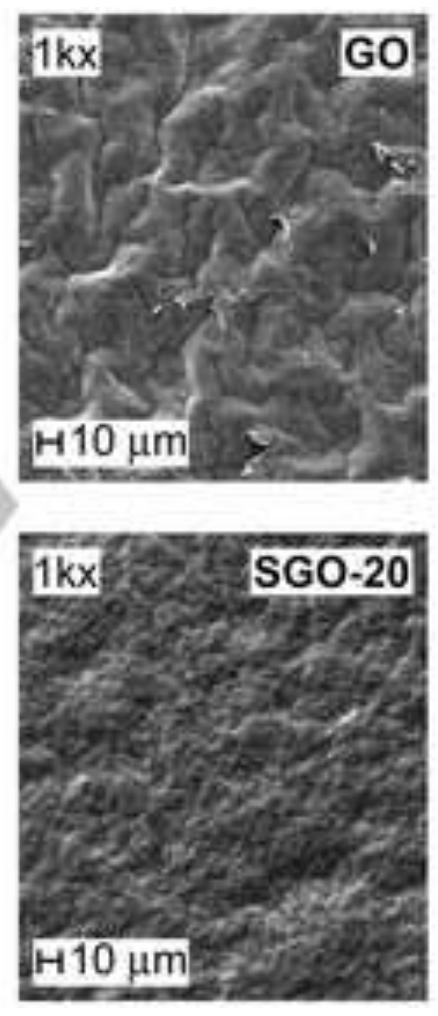

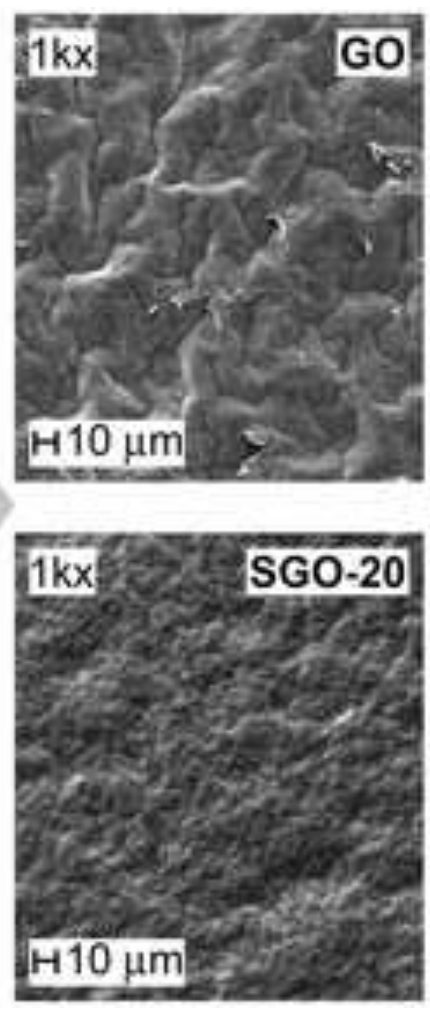

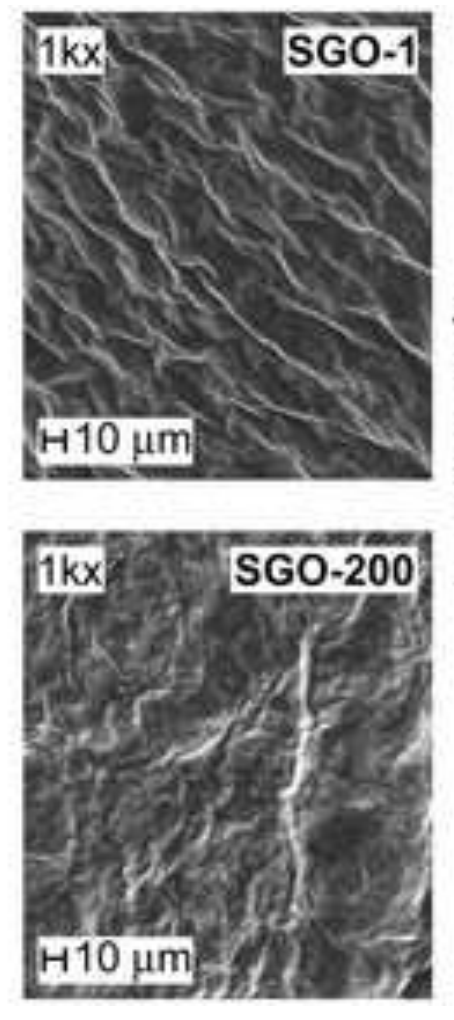

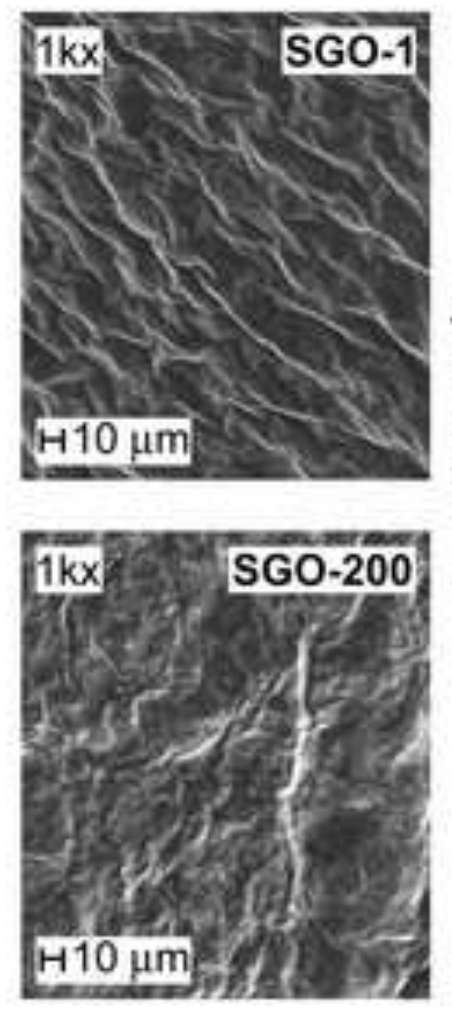

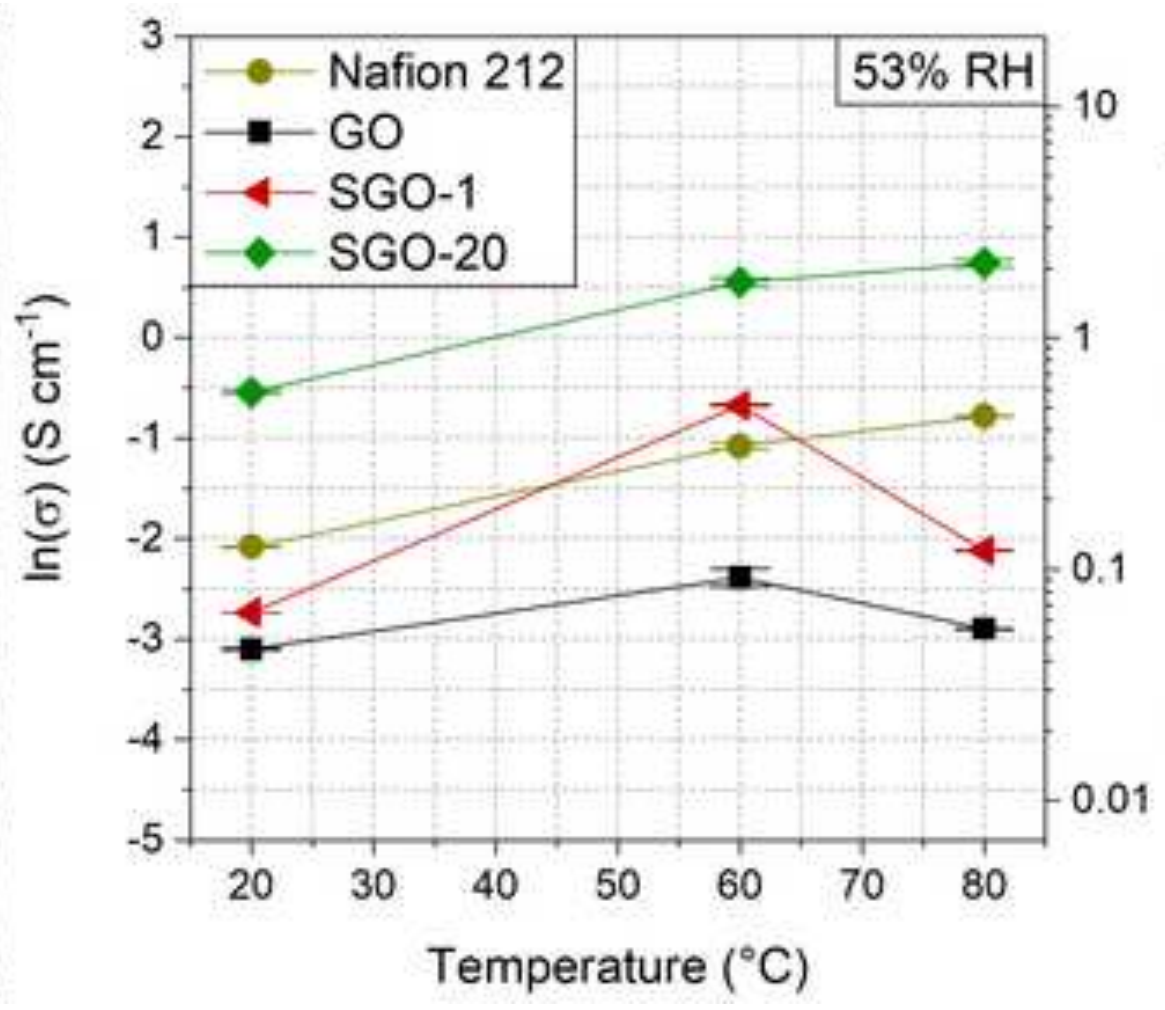

들 


\section{HIGHLIGHTS}

- Preparation of self-assembling sulfonated graphene oxide membranes by simple method

- Analysis of the effect of three different sulfuric acid-to-GO sulfonation ratios

- Sulfonated graphene oxide membranes show enhanced water uptake at low humidity

- Ion exchange capacity of sulfonated GO is improved over that of GO and Nafion ${ }^{\circledR} 212$

- Sulfonation increases the proton conductivity of GO at reduced humidification 


\begin{abstract}
A simple method is reported for the preparation of self-assembling sulfonated graphene oxide membranes (SGO-X) to be studied as a potential proton conductor for proton exchange membrane fuel cells (PEMFCs). The effect of three different sulfuric acid-to-GO molar ratios is investigated, the main aim being the identification of an optimal sulfonation interval ensuring a successful trade-off among composition, structural stability and functional properties. ATR-FTIR and EDX spectroscopies, SEM, thermogravimetry and static contact angle measurements allow to analyze the efficacy of the functionalization of graphene oxide (GO) with sulfonic acid groups $\left(-\mathrm{SO}_{3} \mathrm{H}\right)$ and the uniformity of the component's structure. A preliminary examination of the proton conductivity is performed on the most promising samples (SGO-1, SGO-20) by means of electrochemical impedance spectroscopy (EIS), together with the evaluation of water uptake, ion exchange capacity and degree of sulfonation. This introductory work demonstrates that the proposed SGO-X membranes exhibit notable water-retaining and proton-exchanging properties at elevated temperatures and reduced humidity, compared to pristine GO and Nafion ${ }^{\circledR} 212$ benchmark specimens. Therefore, these innovative self-standing materials are proved to be worthy of additional studies for the optimization of their features, foreseeing the assessment of their behavior as a possible electrolyte in a PEM fuel cell.
\end{abstract}

Keywords: graphene oxide; sulfonation; PEM fuel cell; membrane; proton conductivity 


\section{Introduction}

Over the last few decades, ion-conducting materials have drawn the attention of the scientific community due to their wide applicability in the field of electrochemical energy conversion and storage, ranging from photovoltaic cells [1], batteries [2,3] and supercapacitors [4] to proton exchange membrane fuel cells (PEMFCs) [5,6], one of the most promising technologies for the production of clean, affordable energy.

PEMFCs are expected to play a prominent role in addressing the soaring global energy demand in a greener fashion with respect to currently employed fossil fuels, which cannot be considered anymore a long-term viable option in a world where human population is projected to reach nearly 10 billion people by 2050 , pushing the energy demand to unbearable limits (more than $200000 \mathrm{TWh}$ by 2040) [7,8]. In fact, they allow the transformation of the chemical energy of a fuel directly into electrical current, with a promise of high efficiency and theoretically low-to-zero emissions, since their conversion process relies on a redox reaction between hydrogen and oxygen, whose byproduct is simply water, without involving any combustion $[9,10]$. They are suitable for both stationary and portable applications, owing to their light weight and to a compact and modular design, without moving parts. Nonetheless, a great deal of research is still required to perfect PEMFCs components and to make their performance, cost and durability comparable to conventional energy systems $[11,12]$. In order to achieve this goal, they should also provide an output power density exceeding $1 \mathrm{~W} \mathrm{~cm}^{-2}$, a cost lower than $30 \$ \mathrm{~kW}^{-1}$ and a durability higher than $6000 \mathrm{~h}$ for private transport applications [9,11].

One of the fundamental components of PEMFCs is their proton-conducting electrolyte, which must be carefully designed in order to meet the stringent requirements of the fuel cell environment: high proton conductivity coupled to electrical insulation; low permeability to hydrogen and oxygen; chemical, mechanical and thermal stability [11,13]. The electrolytic material of choice is nowadays Nafion ${ }^{\circledR}$, a perfluorosulfonate ionomer by Chemours characterized by still unparalleled properties: proton conductivity greater than $0.1 \mathrm{~S} \mathrm{~cm}^{-1}$ under humidified conditions, due to the presence of hydrophilic lateral substituents containing sulfonic acid groups $\left(-\mathrm{SO}_{3} \mathrm{H}\right)$; durability over 60000 hours; good thermo-chemical stability and resistance to gas crossover [14-17]. However, Nafion ${ }^{\circledR}$ is quite expensive (about $0.25 € \mathrm{~cm}^{-2}$ [18]) and suffers a severe conductivity drop (down to $0.001 \mathrm{~S} \mathrm{~cm}^{-1}$ ) upon dehydration of the hydrophilic clusters, hindering fuel cell operation above $80{ }^{\circ} \mathrm{C}$ [11]. In addition, it can undergo mechanical deterioration if the water content is excessive, and its mechanical stability is drastically reduced above $100{ }^{\circ} \mathrm{C}$, due to its low glass transition temperature (nearly $110^{\circ} \mathrm{C}$ ). Higher working temperatures and thinner layers may also increase fuel crossover, whereas the presence of hydrogen peroxide radicals can speed up the degradation of the material, inhibiting the use of non-precious catalysts [19].

Hence, huge research efforts have been dedicated in the last few years to finding suitable alternatives that can outperform Nafion ${ }^{\circledR}$ under conditions of high temperatures and low relative humidity $(\mathrm{RH})$, which would substantially enhance both kinetics and efficiency of the redox reaction, while making water management and cell design simpler [20,21]. Among the most recent research trends, graphene oxide (GO) has gained significant interest for the production of both selfstanding [16,17,19,22,23] and hybrid electrolytes, which have been mostly tested for intermediate $\left(80-130{ }^{\circ} \mathrm{C}\right)$ temperature applications. The latter may still be based on Nafion ${ }^{\circledR}$ [24-29] or on more thermally stable polymers, such as sulfonated polyimide [30-32] and sulfonated poly(ether sulfones/ketones) [33-38], in which the addition of either virgin or functionalized GO is expected to improve mechanical, water-retaining and proton-conducting behaviors.

GO is certainly a remarkable candidate for the preparation of self-standing membranes for PEMFCs, since it can be easily processed into single or multilayer films by techniques such as vacuum filtration [39], due to its exceptional selfassembling, mechanical and electrically insulating properties. These features arise from the presence of diverse oxygenbearing functional groups, such as hydroxyl and carboxyl moieties, mostly present at the edges, or carbonyl and epoxide 
ones, prevailing on the basal plane, as proposed by several structural models [40]. These functions promote the formation of hydrophilic regions separated by unfunctionalized, $\mathrm{sp}^{2}$-hybridized graphitic domains that are conversely hydrophobic. The resulting structure, characterized by a large surface area, may substantially increase water permeation, providing a suitable environment for the transport of protons $[19,41]$.

Self-standing pristine GO membranes have been produced by Bayer et al. [17,19]. They measured a slightly higher water uptake with respect to Nafion $^{\circledR}$, though coupled to a larger degree of swelling, making GO more vulnerable to hydrationdriven fractures and deterioration, especially at elevated temperatures [19]. GO also exhibited better mechanical properties than $\mathrm{Nafion}^{\circledR}$ and a permeability to hydrogen three orders of magnitude lower [17]. These features are combined to an encouraging proton conductivity, even if GO's through-plane values $\left(0.55 \mathrm{mS} \mathrm{cm}{ }^{-1}\right)$ proved worse than in-plane ones $\left(49.8 \mathrm{mS} \mathrm{cm}^{-1}\right)$, probably as a consequence of how its flakes are stacked together [17]. Conversely, Bayer et al. also detected a low open circuit voltage $\left(0.42 \mathrm{~V}\right.$ at $\left.80^{\circ} \mathrm{C}\right)$ and a poor fuel cell performance, ascribed to the limited throughplane conductivity, to an unsatisfactory high-temperature durability, and to the strongly reducing hydrogen-containing environment of the anode. The latter leads to a loss of the weaker oxygenated groups, favoring the restoration of the sp ${ }^{2}-$ hybridized graphitic structure and an undesired rise in the electrical conductivity [17,19].

Therefore, innovative approaches involving the modification of GO flakes with alternative functionalities may be studied, with the aim of enhancing both ionic conductivity and structural cohesion of the material. A particularly interesting route consists in the introduction of some acid moieties more tightly bound to the skeleton of GO, such as sulfonic acid ones ($\left.\mathrm{SO}_{3} \mathrm{H}\right)$ analogous to those of Nafion ${ }^{\circledR}$, as proposed by several authors [16,22-25,31-34]. Self-standing sulfonated graphene oxide membranes have been prepared by Kumar et al. [16]. They exhibited an excellent thermo-mechanical stability at $25 \% \mathrm{RH}$, and the insertion of acidic functionalities provided a suitable network for the exchange of protons, with in-plane $\left(40 \mathrm{mS} \mathrm{cm}^{-1}\right)$ and through-plane $\left(12 \mathrm{mS} \mathrm{cm}^{-1}\right)$ conductivities comparable to those of Nafion ${ }^{\circledR}$ at $30{ }^{\circ} \mathrm{C}$ and $100 \%$ RH. Consequently, sulfonation has improved the through-plane value by two orders of magnitude with respect to the ones measured by Bayer et al. for bare GO [17,19], which is in agreement with a remarkable ion exchange capacity $\left(1.1 \mathrm{meq} \mathrm{g}^{-1}\right)$, even greater than for Nafion ${ }^{\circledR}\left(0.93 \mathrm{meq}^{-1}\right)$. Similar results have been found by Jiang et al. [22] and by Sandström et al. [23] but, despite an encouraging fuel cell performance, sulfonated GO's proton-conducting behavior, fuel impermeability, stability and durability are still unsatisfactory.

In order to tackle the previous issues, this introductory work investigates an innovative method for the functionalization of $\mathrm{GO}$ with $-\mathrm{SO}_{3} \mathrm{H}$ moieties. The aim is to produce self-assembling sulfonated graphene oxide (SGO-X) membranes with a simpler sulfonation procedure with respect to the multi-step ones reported in literature. These processes generally involve several precursors such as diazonium salts [16,23,25,28,37], silane molecules [24,31,32,34], chlorosulfonic acid $[33,36]$ or sodium dodecylbenzenesulfonate [22], while the proposed one is based on a reaction with sulfuric acid. The prepared materials have been extensively characterized from the morphological viewpoint by employing scanning electron microscopy, infrared and energy-dispersive X-ray spectroscopies, thermogravimetry and static contact angle analyses. Three different sulfonation ratios have been explored, and the main purpose of this work was to evaluate their effect on functionalization efficacy, structural stability and properties of the components, finally establishing the most appropriate sulfonation range to be considered for future developments of these materials. The most promising SGO-X specimens have also been subjected to water uptake and preliminary proton conductivity tests as a function of temperature and relative humidity; in addition, their ion exchange capacity has been measured and correlated to the corresponding degree of sulfonation. Benchmark samples of unfunctionalized GO and Nafion ${ }^{\circledR} 212$ have been examined as well, and the comparison with the results of SGO-X membranes seems to prove the feasibility of these self-standing components for an eventual test as a potentially novel electrolyte for PEM fuel cells. 


\section{Materials and methods}

\subsection{Materials}

A commercial water-based dispersion of GO $(0.4 \mathrm{wt} \%)$ has been purchased from Graphenea Inc, while Durapore ${ }^{\circledR}$ polyvinylidene fluoride (PVDF) filter disks $(0.22 \mu \mathrm{m}$ pore size, hydrophilic) have been supplied by Merck Millipore. Concentrated sulfuric acid (ACS reagent, 95.0-97.0\%), magnesium nitrate hexahydrate $\left(\mathrm{Mg}\left(\mathrm{NO}_{3}\right)_{2} \cdot 6 \mathrm{H}_{2} \mathrm{O}\right.$, ACS reagent, 99.0\%), sodium chloride ( $\mathrm{NaCl}, \mathrm{ACS}$ reagent, $\geq 99.0 \%$ ), sodium hydroxide pellets $(\mathrm{NaOH}, \mathrm{ACS}$ reagent, $\geq 97.0 \%)$ and Nafion $^{\circledR} 212$ sheets (equivalent weight $1100 \mathrm{~g} \mathrm{eq}^{-1}$, thickness $=50.8 \mu \mathrm{m}$ ), have been acquired from Sigma-Aldrich Corporation.

\subsection{Membranes production}

Virgin GO membranes have been produced with a well-established procedure within our research group [42]. $25 \mathrm{~mL}$ of the dispersion, containing $100 \mathrm{mg}$ of GO, have been placed into a beaker and subjected to $1 \mathrm{~h}$ of an ultrasound bath in the LABSONIC LBS 1-H3 by Falc Instruments S.r.l., so as to improve its homogeneity. Ice has been added to the bath outside the beaker in order to avoid an excessive temperature increase, which might lead to an unwanted reduction of GO. Afterwards, the dispersion has been vacuum-filtered on a PVDF filter disk placed inside a Büchner funnel of $7.5 \mathrm{~cm}$ in diameter; at the end of the filtration process, the funnel has been detached from the flask and placed in oven at $40{ }^{\circ} \mathrm{C}$ for a few hours, in order to let the deposit dry and self-assemble into the membrane.

The general methodology for the sulfonation of GO has been based on the one proposed by Cheng et al. [43] and has been adapted to accomplish the formation of a self-standing membrane; sulfuric acid has been employed as functionalizing agent also by Gahlot et al. [33], even if in combination with chlorosulfonic acid, and by Xu et al. [44]. Thus, $25 \mathrm{~mL}$ of the GO dispersion have been introduced into a round-bottomed flask and underwent 10 min of a mild ultrasound bath, again with the external addition of ice to prevent overheating. Then, the desired amount of sulfuric acid has been incorporated dropwise. Subsequently, the flask with the resulting solution has been immersed into an oil bath, connected to a reflux condenser and submitted to $3 \mathrm{~h}$ of magnetic stirring $(850 \mathrm{rpm})$ at $25^{\circ} \mathrm{C}\left( \pm 2{ }^{\circ} \mathrm{C}\right)$ followed by $3 \mathrm{~h}$ at $100{ }^{\circ} \mathrm{C}( \pm$ $5{ }^{\circ} \mathrm{C}$ ), so that $\mathrm{GO}$ and sulfuric acid could accurately mix and the functionalization could take place. Afterwards, the mixture has been diluted with $300 \mathrm{~mL}$ of deionized water so as to increase its $\mathrm{pH}$ and to prevent damages to the vacuum pump from the acid vapors. Finally, vacuum filtration has been carried out, followed by drying in oven at $50{ }^{\circ} \mathrm{C}$ for several hours, until the SGO-X membrane has been properly assembled on the PVDF filter disk.

Three different sulfuric acid-to-GO molar ratios have been taken under consideration, namely 1, 20 and 200; they have been calculated by considering a rough estimate of the molecular weight of GO $\left(\approx 35.3 \mathrm{~g} \mathrm{~mol}^{-1}\right)$. The latter has been derived from an empirical formula $\left(\mathrm{C}_{1.5} \mathrm{H}_{0.2} \mathrm{~N}_{0.01} \mathrm{~S}_{0.03} \mathrm{O}\right)$ obtained from the elemental analysis of the dispersion [45]; even if the precise structure of GO is still unknown, this formula is in agreement with several widely accepted structural models, which suggest that the carbon-to-oxygen ratio of GO may vary between 1.5 and 4 [40]. The specimens produced with the previously described method have been labeled as SGO-X, where X stands for the value of the acid-to-GO molar ratio. The highest one $(X=200)$ has been computed from the volume of sulfuric acid $(30 \mathrm{~mL})$ employed by Cheng et al. [43], and has been later reduced to the tentative values of $X=1(0.15 \mathrm{~mL})$ and $X=20(3 \mathrm{~mL})$, in order to evaluate their effect on the functionalization process and on the structure of the membrane. 


\subsection{Morphological characterization}

Scanning electron microscopy (SEM) and energy-dispersive X-ray (EDX) spectroscopy have been performed on all asprepared samples of GO and SGO-X membranes. The employed apparatus consisted of the SEM model EVO 50 EP by Carl Zeiss AG, coupled with the INCA 200 PENTAFET LZ4 EDX spectrometer by Oxford Instruments plc. Both SEM and EDX spectroscopy tests have employed an accelerating voltage of $20 \mathrm{kV}$ and a maximum current probe of $100 \mathrm{pA}$; a chamber pressure of $10^{-4} \mathrm{~Pa}$ has been applied for SEM imaging at $1 \mathrm{kx}, 5 \mathrm{kx}, 10 \mathrm{kx}$ of magnification, while EDX measurements have adopted a variable pressure in the range of 30-40 $\mathrm{Pa}$ and 500x of magnification.

Fourier transform infrared (FTIR) spectroscopy has been carried out in attenuated total reflection (ATR) on specimens of all as-prepared membranes. The ThermoElectron Continu $\mu m$ IR microscope by Thermo Fisher Scientific has been used; the instrument was equipped with a single reflection silicon crystal in combination with an MCT detector cooled by liquid nitrogen. All spectra have been acquired between 650 and $4000 \mathrm{~cm}^{-1}$ with 128 scans and a resolution of $4 \mathrm{~cm}^{-1}$. Thermogravimetric measurements have been conducted with the EXSTAR 6000 TG/DTA 6300 by Seiko Instruments Inc; an inert nitrogen atmosphere, fluxed at $55 \mathrm{~mL} \mathrm{~min}^{-1}$, has been applied in order to avoid an undesired oxidation of the sample, and heating has been provided at a rate of $10{ }^{\circ} \mathrm{C} \mathrm{min}^{-1}$ between room temperature and $1000{ }^{\circ} \mathrm{C}$.

The optical static contact angle (OCA) has been determined with the video-based OCA 15plus system by DataPhysics Instruments $\mathrm{GmbH}$, equipped with a $\mathrm{CCD}$ video-camera with a resolution of $752 \times 582$ pixels and capable of recording up to 50 frames $\mathrm{s}^{-1}$.

\subsection{Water uptake tests}

Water uptake and swelling ratio have been measured on samples of Nafion ${ }^{\circledR} 212$, GO, SGO-1 and SGO-20 cut to a size of roughly $35 \times 10 \mathrm{~mm}^{2}$ so as to have a sufficient surface area and weight to obtain meaningful results. The experimental test has been performed in a lab-built humid chamber, developed in order to replicate as faithfully as possible the environmental conditions of a PEMFC. This setup allowed to set the temperature to $20,40,60,80$ and $100{ }^{\circ} \mathrm{C}$ in different test runs by means of a recirculating oil bath external to the chamber. The level of humidification has been controlled by employing a fixed volume $(600 \mathrm{~mL})$ of deionized water or of a saturated solution of magnesium nitrate hexahydrate providing $95 \%$ and $53 \%$ relative humidity, respectively. These values can be considered fairly constant in the range of $20-100^{\circ} \mathrm{C}$, as it has been proved in a previous work [46].

The specimens have been first dried in oven for $2 \mathrm{~h}$ at $60^{\circ} \mathrm{C}$, then put into a sealed bag and weighed immediately; their dry thickness has been determined with a digital micrometer $( \pm 1 \mu \mathrm{m})$. Afterwards, they have been mounted on a Teflon ${ }^{\circledR}$ sample holder and suspended in the humid atmosphere for $1 \mathrm{~h}$ at the desired temperature and humidity. Subsequently, they have been taken down, quickly dried with a piece of paper, and their wet weight and thickness have been finally evaluated. Water uptake and swelling ratio have been computed using Equations 1 and 2, where $w_{\text {wet }}$ and $w_{d r y}$ are the wet and dry weights of the samples, while $t_{w e t}$ and $t_{d r y}$ are their wet and dry thicknesses, respectively:

$$
\begin{gathered}
W U(\%)=\frac{w_{w e t}-w_{d r y}}{w_{d r y}} \cdot 100(1) \\
S R(\%)=\frac{t_{w e t}-t_{d r y}}{t_{d r y}} \cdot 100(2)
\end{gathered}
$$




\subsection{Ion exchange capacity and degree of sulfonation}

The ion exchange capacity (IEC, meq $\mathrm{g}^{-1}$ ) has been assessed with a classical acid-base titration technique, and this work has followed the methodology proposed by the authors of [36]. Specimens of all GO-based membranes and of Nafion ${ }^{\circledR}$ 212 have been analyzed. They have been dried in oven at $60{ }^{\circ} \mathrm{C}$ for $1 \mathrm{~h}$, before determining their dry weight; then, they have been equilibrated at room temperature for $48 \mathrm{~h}$ into $250 \mathrm{~mL}$ of a concentrated aqueous solution of $\mathrm{NaCl}(2 \mathrm{M})$, in order to favor the exchange between $\mathrm{H}^{+}$ions from oxygenated and sulfonic acid moieties and $\mathrm{Na}^{+}$ones from the salt. Eventually, the samples have been removed from the solution, which has been titrated against controlled volumes of a solution of $\mathrm{NaOH}(0.01 \mathrm{M})$. The ion exchange capacity may be defined as the milliequivalents of ionic sites containing exchangeable protons per gram of dried membrane and can be obtained from Equation 3:

$$
I E C=\frac{V_{\mathrm{NaOH}} \cdot C_{\mathrm{NaOH}}}{w_{d r y}}
$$

$V_{\mathrm{NaOH}}(\mathrm{mL})$ is the volume of the $\mathrm{NaOH}$ solution corresponding to the turning point of the titration curve, $\mathrm{C}_{\mathrm{NaOH}}(\mathrm{M})$ is its concentration and $w_{d r y}(\mathrm{~g})$ is the dry weight of the specimen before equilibration.

The ion exchange capacity can also be correlated to the degree of sulfonation (DS, \%), describing the efficiency of insertion of sulfonic groups onto the original structure of the molecule. In the case of SGO-X membranes, the degree of sulfonation may be calculated provided that the molecular weight of GO ( $\mathrm{MW}_{\mathrm{GO}}$, as estimated in Section 2.2) and of $\mathrm{SO}_{3} \mathrm{Na}$ functionalities $\left(\mathrm{MW}_{\mathrm{f}}=103 \mathrm{~g} \mathrm{~mol}^{-1}\right)$ are known [47]. In fact, the starting structure is the one of GO, onto which $\mathrm{SO}_{3} \mathrm{H}$ groups are introduced; however, since the DS is related to the IEC, it has to be considered that only the moieties that effectively replace $\mathrm{H}^{+}$ions with $\mathrm{Na}^{+}$ones may contribute to the determination of this parameter, defined in Equation 4 [47]:

$$
D S_{S G O-X}=\frac{M W_{G O} \cdot I E C}{\left[1000-\left(M W_{f} \cdot I E C\right)\right]} \cdot 100=\frac{35.3 \cdot I E C}{[1000-(103 \cdot I E C)]} \cdot 100(4)
$$

In the case of Nafion ${ }^{\circledR} 212$, the molecular weight $\left(\mathrm{MW}_{\text {Nafion }}\right)$ can be identified according to its structure [18], but assuming the presence of a hydrogen atom, rather than of the $-\mathrm{SO}_{3} \mathrm{H}$ group, as the terminal of the lateral substituent. In this way $\mathrm{MW}_{\text {Nafion }}=452 \mathrm{~g} \mathrm{~mol}^{-1}$ is obtained, while $\mathrm{MW}_{\mathrm{f}}$ remains the same as for sulfonated graphene oxide. The corresponding degree of sulfonation is calculated as in Equation 5:

$$
D S_{\text {Nafion }}=\frac{M W_{\text {Nafion }} \cdot I E C}{\left[1000-\left(M W_{f} \cdot I E C\right)\right]} \cdot 100=\frac{452 \cdot I E C}{[1000-(103 \cdot I E C)]} \cdot 100(5)
$$

\subsection{Proton conductivity}

The assessment of the proton conductivity has been carried out by means of electrochemical impedance spectroscopy (EIS), with a methodology similar to the one of water uptake tests described in Section 2.4. Specimens of Nafion ${ }^{\circledR} 212$, GO, SGO-1 and SGO-20 of about $35 \times 10 \mathrm{~mm}^{2}$ in size have been dried in oven at $60{ }^{\circ} \mathrm{C}$ for $2 \mathrm{~h}$, before being clamped on a Teflon ${ }^{\circledR}$ substrate between two metal electrodes. Then, the sample holder has been inserted for $1 \mathrm{~h}$ in the lab-made humid chamber, whose temperature and humidification conditions have been set respectively to $20,60,80{ }^{\circ} \mathrm{C}$ and to 53 , 
95\% RH in different test runs. The electrochemical analysis has been conducted with the Bode analyzer tool of the STEMlab ${ }^{\mathrm{TM}} 125-14$ board by Red Pitaya. A potentiostatic mode has been used, setting the signal amplitude to $0.5 \mathrm{~V}$ and recording the current response by sweeping the frequency in the $1 \mathrm{~Hz}-10 \mathrm{MHz}$ range. Three measurements have been performed on every specimen for each temperature-humidity pair, so as to ensure reliability. The resulting Bode diagrams have been converted into Nyquist plots, which have been fitted in the software ZView ${ }^{\circledR}$ by Scribner Associates Inc. This procedure allowed to extract the average internal resistance $R_{i}(\Omega)$ of the membrane and to correlate it to the proton conductivity $\sigma\left(\mathrm{S} \mathrm{cm}^{-1}\right)$ by means of the second Ohm's law, as shown in Equation 6, where $w(\mathrm{~cm})$ and $t(\mathrm{~cm})$ are, respectively, specimen's width and thickness, $d(\mathrm{~cm})$ is the separation between the metal electrodes and $\rho(\Omega \mathrm{cm})$ is the resistivity:

$$
\sigma=\frac{1}{\rho}=\frac{d}{R_{i} \cdot w \cdot t}(6)
$$

\section{Results and discussion}

\subsection{Membranes production}

Pictures of the as-produced membranes have been taken with a digital camera and are reported in the Supplementary Information (Figure S1). They exhibit a diameter of about $7.5 \mathrm{~cm}$ and a thickness growing from $13 \mu \mathrm{m}$ for GO to 27 and $76 \mu \mathrm{m}$ for SGO-1 and SGO-20, respectively, while SGO-200 fragments display values greater than $100 \mu \mathrm{m}$. It is clear how GO has lost its self-assembling properties by rising the acid-to-GO molar ratio, as if it has been reduced by the sulfonation reaction; in fact, visible cracks have formed in the case of SGO-20 (Figure S1C), while the flakes of SGO200 (Figure S1D) have coalesced into thick islands. This outcome is odd considering that sulfuric acid is an oxidizing agent and sulfur is already in its maximum oxidation state (+6). Perhaps, it may be ascribed to the combination of a sort of leaching effect, caused by the acid mixture on oxygenated groups, with a too elevated process temperature. This synergistic action can find evidence in the fact that, by increasing the amount of acid employed for the sulfonation reaction, GO flakes already tended to aggregate in coarse particles inside the aqueous dispersion. This phenomenon may be explained by the possible removal of oxygen-bearing functions, resulting in a higher hydrophobicity of the material and in the loss of its self-assembling properties, compromising the formation of a uniform membrane $[35,48]$.

\subsection{Morphological characterization}

SEM experiments, carried out on all virgin samples of GO and SGO-X membranes, allow to evaluate how their surface morphology has been affected by the functionalization with sulfuric acid. The corresponding images, acquired at multiple magnifications, are shown in Figure 1. They confirm the relatively uniform surface appearance of all samples and a slight growth in wrinkles and asperities at higher acid-to-GO molar ratios. In fact, it is evident that both membranes of pristine GO (Figure 1A-C) and SGO-1 (Figure 1D-F) seem smoother and flatter than SGO-20 (Figure 1G-I) and SGO-200 (Figure 1J-L) ones, especially considering the largest magnifications. Nonetheless, some differences may also be identified between the structures of virgin GO and SGO-1, since the former looks bumpier and the latter more wrinkled. This can indicate that even if the quantity of sulfuric acid used for the functionalization of SGO-1 was extremely low, it still had some effects on the morphology. 

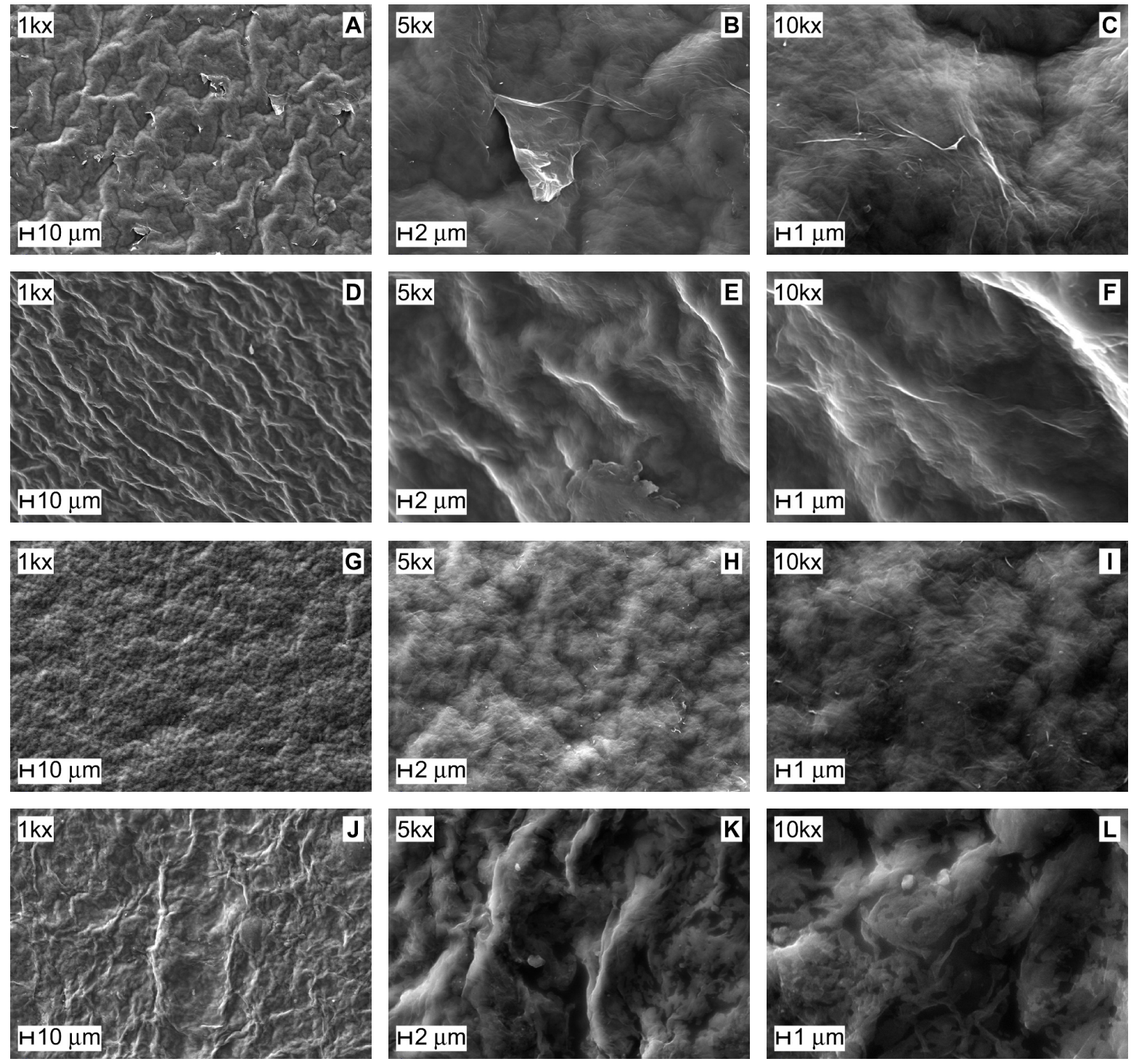

Figure 1. SEM pictures at $1 \mathrm{kx}, 5 \mathrm{kx}$ and $10 \mathrm{kx}$ of (A)-(C) GO, (D)-(F) SGO-1, (G)-(I) SGO-20 and (J)-(L) SGO-200.

The semi-quantitative EDX analysis is summarized in Figure 2 and evidences how the weight percentages of both oxygen and sulfur rise together with the acid-to-GO molar ratio, even in the case of SGO-1. This can be a confirmation of the effective introduction of sulfonic acid functions on the flakes of GO. In fact, even if the reaction involves a partial substitution of oxygen-bearing groups, according to the mechanism proposed by multiple authors [24,35,37], the oxygen content is still expected to increase, since there are three oxygen atoms for every $-\mathrm{SO}_{3} \mathrm{H}$ moiety that is inserted. In the case of GO, the results of EDX spectroscopy also allow to validate the empirical formula $\left(\mathrm{C}_{1.5} \mathrm{H}_{0.2} \mathrm{~N}_{0.01} \mathrm{~S}_{0.03} \mathrm{O}\right)$ reported in Section 2.2, since a carbon-to-oxygen ratio of about 1.6 can be obtained from the atomic percentages $(61.97 \%$ for carbon, $37.34 \%$ for oxygen). 


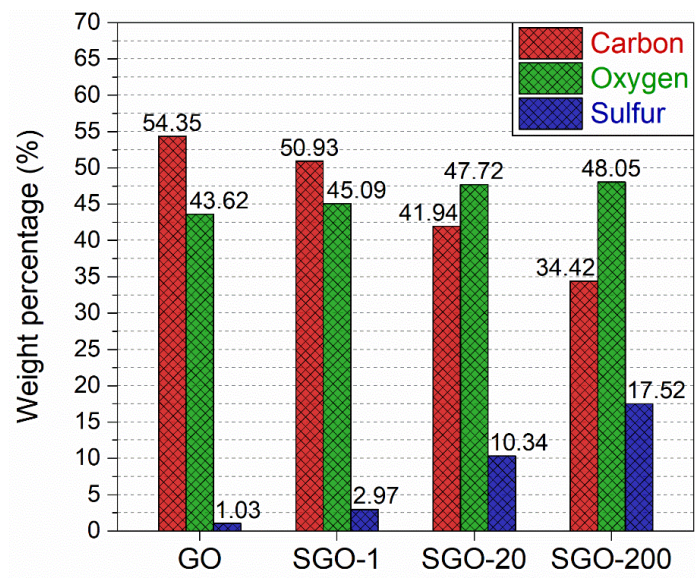

Figure 2. Semi-quantitative EDX spectroscopy results for as prepared GO-based membranes.

ATR-FTIR spectroscopy enables to identify the presence of the characteristic vibrations of sulfonic acid groups after the functionalization of GO. The corresponding spectra are displayed in Figure 3 and can be considered more indicative of a surface analysis rather than of a bulk one, given the low penetration depth (a few micrometers) of the evanescent wave produced in ATR conditions. GO-based membranes are extremely complex systems, even more so after the sulfonation reaction, and the precise knowledge of both type and disposition of their functional groups is still limited. Hence, the following band assignments should be considered only from a qualitative point of view, as they arise from the overlap of multiple contributions that should be unfolded with detailed computational models.

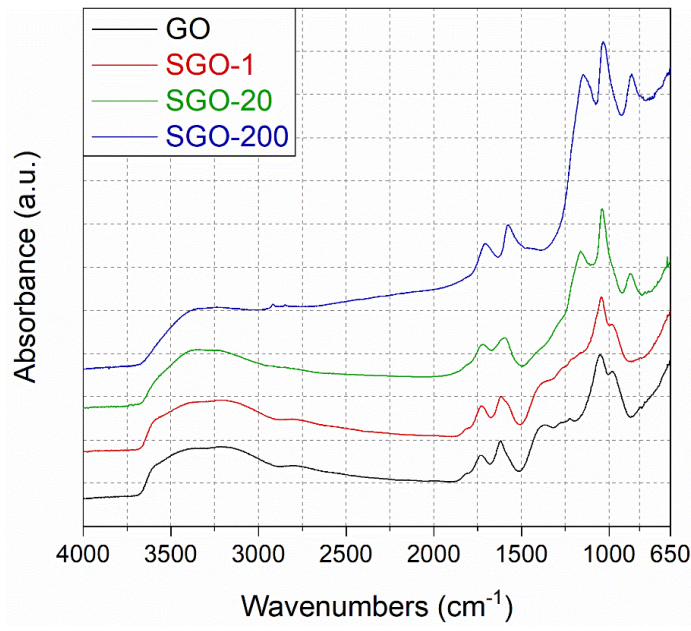

Figure 3. ATR-FTIR spectra of virgin GO and functionalized SGO-X membranes.

Starting from the spectrum of GO, recorded as a reference, one can witness the presence of all the characteristic bands of the material: the one at $1619 \mathrm{~cm}^{-1}$ can be related to the $\mathrm{O}-\mathrm{H}$ bending vibration of adsorbed water, while that at $1729 \mathrm{~cm}^{-1}$ may be ascribed to the stretching vibration of $\mathrm{C}=\mathrm{O}$ from carbonyl and carboxyl groups [26,30,49]. The latter also displays a small shoulder at $1818 \mathrm{~cm}^{-1}$, which could be associated to $\mathrm{C}=\mathrm{O}$ stretching as well, but from anhydride moieties. Then, the band between 1200 and $1300 \mathrm{~cm}^{-1}$ might be attributed to the stretching vibrations of -COC- from the epoxide group, and possibly from other functionalities like ether, ester and anhydride ones; on the other hand, the adjacent band in the $1300-1400 \mathrm{~cm}^{-1}$ range could be assigned to $\mathrm{C}-\mathrm{OH}$ stretching in carboxyl moieties and to $\mathrm{O}-\mathrm{H}$ bending in hydroxyl, 
carboxyl and phenol ones [37,49,50]. Finally, two bands may be found at 981 and $1051 \mathrm{~cm}^{-1}$, potentially related to C-O stretching from unstable groups (lactols, peroxides) and to the stretching of $\mathrm{C}-\mathrm{OH}$ bonds from hydroxyl moieties [51]. The spectrum of SGO-1 exhibits two slight differences with respect to the one of virgin GO. The former is a contribution that rises at $1580 \mathrm{~cm}^{-1}$, possibly corresponding to the stretching vibration of $\mathrm{sp}^{2}$, non-oxidized $\mathrm{C}=\mathrm{C}$ bonds in graphitic domains; this might indicate that the number of oxygenated functions of SGO-1 is reduced as a consequence of the sulfonation process [50]. The latter is a small increase in the intensity of the band between 1100 and $1300 \mathrm{~cm}^{-1}$, which corresponds to the region of the stretching of $\mathrm{O}=\mathrm{S}=\mathrm{O}$ bonds in sulfonic groups $[33,44]$. Thus, these results confirm that some changes are probably introduced in the structure of GO even with the lowest sulfonation ratio. The previous interpretation is supported by the formation of two new bands in SGO-20 and SGO-200 spectra: one is between 870 and $880 \mathrm{~cm}^{-1}$ and is compatible with the stretching of $\mathrm{S}-\mathrm{O}$ bonds in sulfinic $\left(-\mathrm{SO}_{2} \mathrm{H}\right)$ and sulfonic $\left(-\mathrm{SO}_{3} \mathrm{H}\right)$ functionalities $[35,44,52]$; the other is in the $1143-1153 \mathrm{~cm}^{-1}$ range and could be associated to the symmetric stretching vibrations of $\mathrm{O}=\mathrm{S}=\mathrm{O}$ from sulfonic moieties $[33,35,43]$. In conjunction with the rising of these bands, one may notice the disappearance of the modes about $981 \mathrm{~cm}^{-1}$ and of those between 1300 and $1400 \mathrm{~cm}^{-1}$, witnessed in pristine GO; this might imply that the sulfonation process resulted in the partial removal of less stable lactol, peroxide and carboxyl moieties [53,54].

Then, it can be seen that the membranes of pristine GO and SGO-1 exhibit a structured band in the $3000-3700 \mathrm{~cm}^{-1}$ range, consisting of three main contributions centered about 3200,3400 and $3600 \mathrm{~cm}^{-1}$; they could be assigned to the stretching of $\mathrm{OH}$ groups in carboxylic acid functions, free water alcohols/phenols and hydroxyl groups, respectively $[53,54]$. The last one might suggest that these membranes possess a characteristic structural order, because the steric hindrance caused by an ordered array of atoms can partially prevent the development of hydrogen-bonding interactions from hydroxyl groups. This could lead to the rising of the free $\mathrm{OH}$ stretching band at $3600 \mathrm{~cm}^{-1}$, which cannot be found in SGO-20 and SGO-200 spectra, possibly indicating an increase in the degree of structural disorder with a larger acidto-GO molar ratio $[53,54]$.

Due to the limited knowledge of the structure of GO, its functionalization chemistry is complex and not well understood yet; however, according to the widely accepted Lerf-Klinowski model [40], the most reactive moieties are epoxide and hydroxyl ones on the basal plane, carboxyl and carbonyl ones on the edges [24,35,37]. The previous hypotheses are supported by the acquired spectra and suggest a probable reduction of the basal plane of GO during the functionalization process; this effect appears to be enhanced by rising the sulfonation ratio and might also be related to the fact that the stretching of $\mathrm{sp}^{2}$ graphitic domains $\left(1580 \mathrm{~cm}^{-1}\right)$ seems to become dominant over the one of O-H bending $\left(1619 \mathrm{~cm}^{-1}\right)$. The results of thermogravimetric analyses are reported in Figure 4. They supply information on the thermal decomposition of the membranes and on the variation in the content of oxygen-containing moieties after the sulfonation of GO, as well as on the consequent presence of the corresponding $-\mathrm{SO}_{3} \mathrm{H}$ functionalities.

If pristine GO is considered (Figure 4A), two fundamental weight losses may be identified: the one of the order of $15 \%$ below $100{ }^{\circ} \mathrm{C}$ corresponds to the evaporation of water molecules physically adsorbed on hydrophilic groups; on the other hand, the significant drop (25\%) taking place in the proximity of $200{ }^{\circ} \mathrm{C}$ can be associated to the decomposition of oxygenated functionalities (carboxyl, epoxide, hydroxyl and carbonyl) and to the release of $\mathrm{CO}$ and $\mathrm{CO}_{2}[26,33]$. Finally, there is a mass loss of nearly $35 \%$ above $550{ }^{\circ} \mathrm{C}$, which may be ascribed to the breakdown of the GO framework, because the elevated temperature induces its almost complete reduction; thus, inter-sheet interactions are weakened at such elevated temperatures and the stacking of GO layers is destroyed [30,38].

A similar behavior is witnessed in the case of SGO-1 (Figure 4A), in which the loss of oxygenated moieties is more pronounced (almost $30 \%$ ) and seems to start at lower temperatures $\left(\approx 150{ }^{\circ} \mathrm{C}\right)$; this might suggest the presence of $-\mathrm{SO}_{3} \mathrm{H}$ groups weakly bonded to the framework of GO, perhaps through oxygen atoms. Moreover, a slight change in the slope 
of the curve occurs between 250 and $300{ }^{\circ} \mathrm{C}$, corresponding to a mass drop of the order of $6 \%$ and potentially linked to the removal of sulfonated functions covalently bonded to the basal plane [36,43]. These findings are in agreement with what can be observed in the thermogram of a Nafion ${ }^{\circledR} 212$ membrane (Figure 4B), in which the loss of sulfonic groups takes place between 280 and $380^{\circ} \mathrm{C}$, before the breakdown of both side chains and PTFE backbone $\left(400-600{ }^{\circ} \mathrm{C}\right)[28,55]$. The shift to higher temperatures of the decomposition range hints that these moieties are more stable in Nafion ${ }^{\circledR} 212$ than in SGO-1. Even so, these results seem to confirm a small sulfonation even with a 1:1 molar ratio, as indicated by ATRFTIR and EDX spectra of SGO-1.
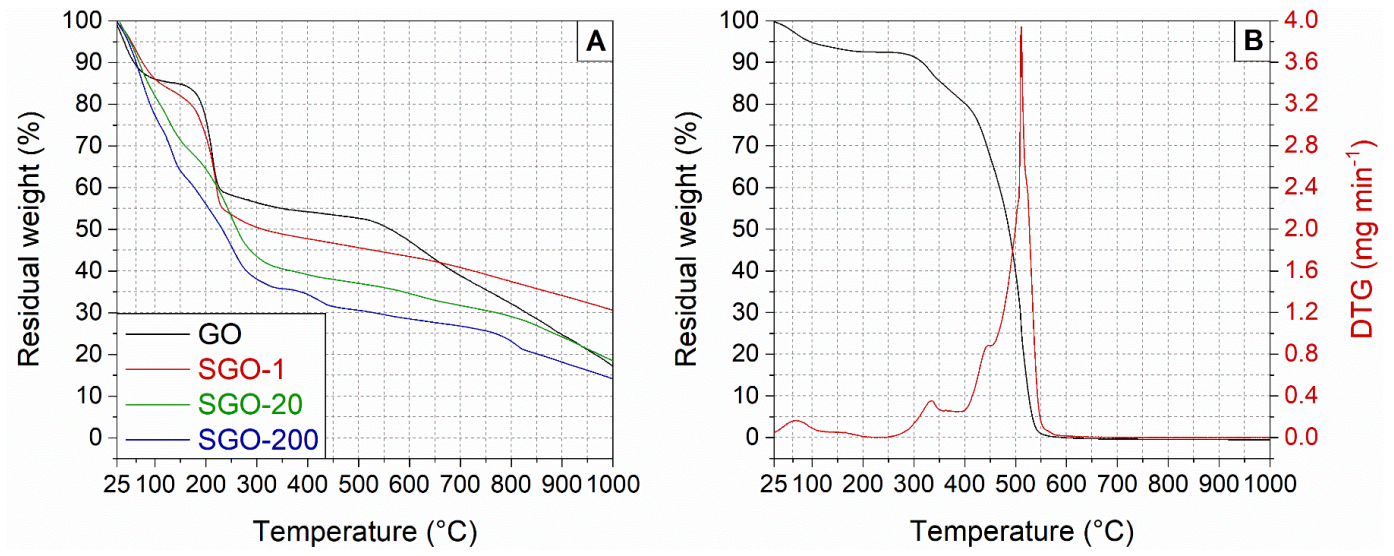

Figure 4. (A) Thermogravimetric curves for as prepared GO and SGO-X membranes. (B) Residual weight and first derivative (DTG) plots for Nafion ${ }^{\circledR} 212$.

By increasing the acid-to-GO molar ratio, the shape of the thermograms of SGO-20 and SGO-200 changes, as visible in Figure 4A. In particular, the mass drop at $110-150{ }^{\circ} \mathrm{C}$ might be again associated to the removal of weak sulfonic acid groups, but it takes place at lower temperatures with respect to SGO-1, like the loss of covalently linked moieties, which seems to start at about $170^{\circ} \mathrm{C}$. The result is an almost continuous weight decrease up to $300^{\circ} \mathrm{C}$, indicating a lower thermal stability of SGO-20 and SGO-200 as against GO and SGO-1; in fact, the former see their weight nearly cut in half below $200{ }^{\circ} \mathrm{C}$, while the latter lose only $15 \%$ of their mass in the same temperature range. Hence, it looks clear that an excessive amount of sulfuric acid is detrimental for the thermal stability of the component.

The OCA has been assessed with the purpose of checking how the sulfonation of GO has affected the behavior of the membranes' surface when in contact with water. This is an important information since the electrolytic material is expected to be hydrophilic. The results of the measurements are reported with the corresponding images in Figure 5 and they are an average of five to ten values taken in different positions of the surface of the sample.
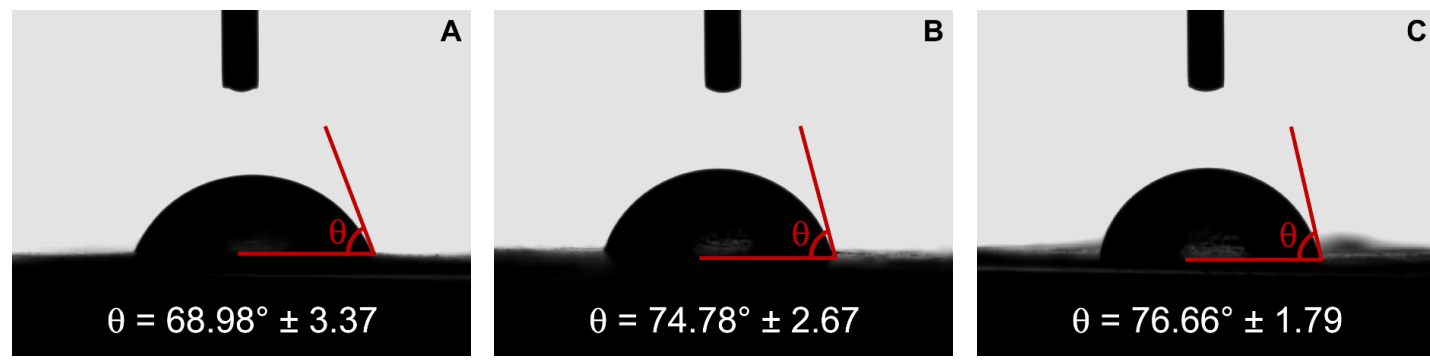

Figure 5. OCA measurements for (A) Unfunctionalized GO, (B) SGO-1 and (C) SGO-20. 
It has been impossible to perform the test on SGO-200, because its large surplus of sulfuric acid made it so hydrophilic that any deposited droplet has been adsorbed immediately. Considering the other specimens, the OCA is in all cases lower than $90^{\circ}$, indicating a markedly water affinity of the surfaces of both pristine GO (Figure 5A) and sulfonated membranes; this is an expected outcome given the hydrophilic nature of both oxygenated and $-\mathrm{SO}_{3} \mathrm{H}$ groups [52]. The contact angle appears slightly higher for SGO-1 (Figure 5B) and SGO-20 (Figure 5C); in the case of a moderately hydrophilic material, this may be explained by a possibly larger surface wrinkledness [56], as observed in SEM pictures.

\subsection{Water uptake tests}

Regarding sulfonated membranes, water uptake tests have been conducted on samples of SGO-1 and SGO-20 only, while SGO-200 has been discarded, given the impossibility to obtain a self-assembled membrane; unfunctionalized GO and Nafion ${ }^{\circledR} 212$ have been analyzed too as a reference. The results are shown in Figures 6 and 7.
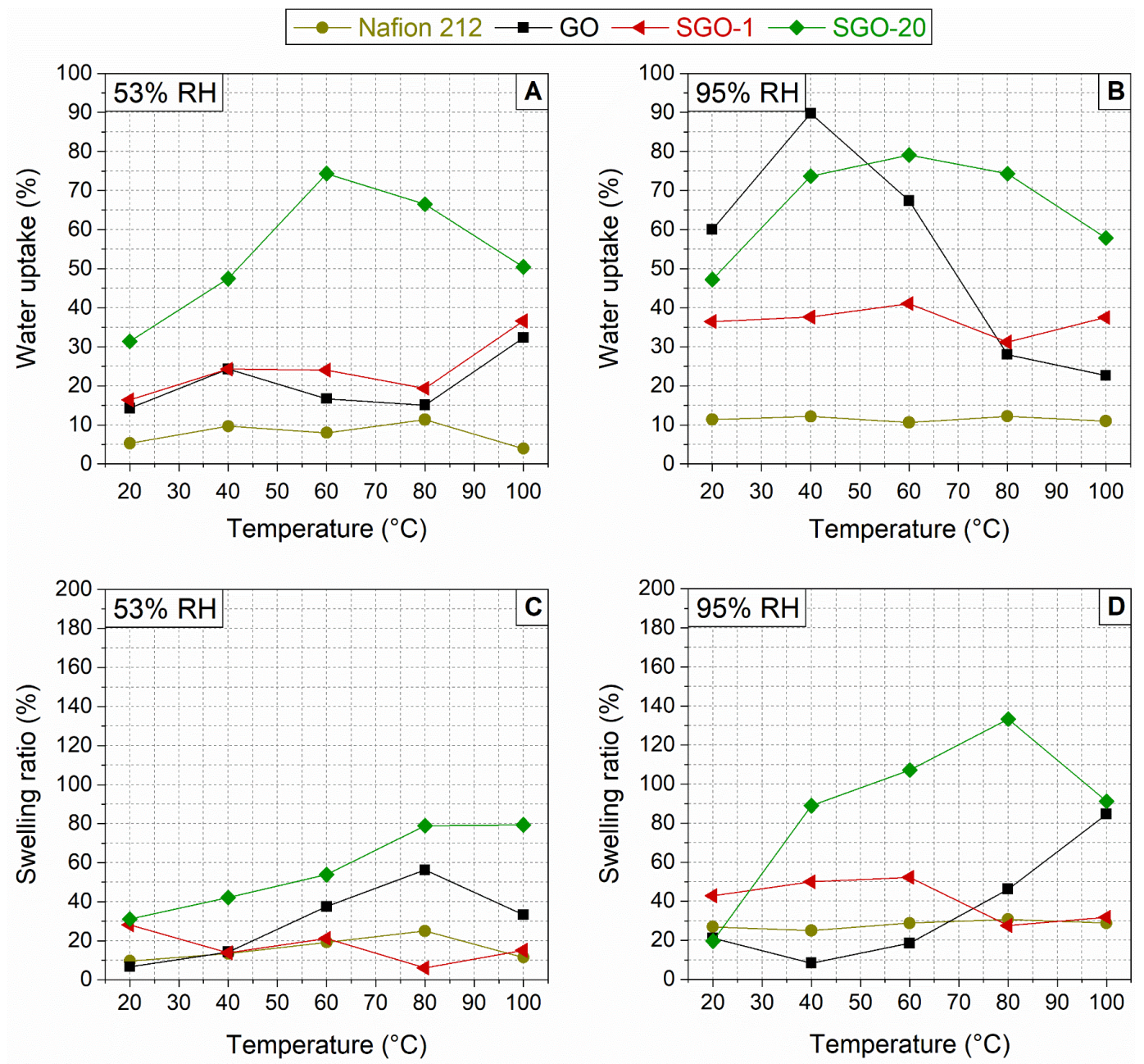

Figure 6. Comparison of water uptake (WU) and swelling ratio (SR) tests performed on Nafion ${ }^{\circledR} 212$, GO and SGO-X membranes in the $20-100{ }^{\circ} \mathrm{C}$ temperature range: (A) WU, 53\% RH; (B) WU, 95\% RH; (C) SR, 53\% RH; (D) SR, 95\% RH.

Starting from Nafion ${ }^{\circledR} 212$, it can be seen that both water uptake and swelling ratio increase slightly with the relative humidity, as expected. The former (Figure 7A) displays average values of $7.64 \pm 3.06 \%$ and $11.47 \pm 0.70 \%$ at $53 \%$ and 95\% RH, respectively. The latter (Figure 7B), for which the limited accuracy of the digital micrometer must be kept in mind, is $15.77 \pm 6.29 \%$ at $53 \% \mathrm{RH}$ and $28.08 \pm 2.19 \%$ at $95 \% \mathrm{RH}$. Water uptake results are in agreement with those 
indicated in a previous study by Shi et al. [57], who used a method similar to the one employed in the present research, and one can see a fairly constant behavior by varying the temperature at fixed relative humidity. Only a small drop can be noticed in the water uptake at $100{ }^{\circ} \mathrm{C}$ and $53 \% \mathrm{RH}$ (Figure $6 \mathrm{~A}$ ), which confirms how Nafion ${ }^{\circledR}$ suffers from dehydration at elevated temperatures and reduced humidification.
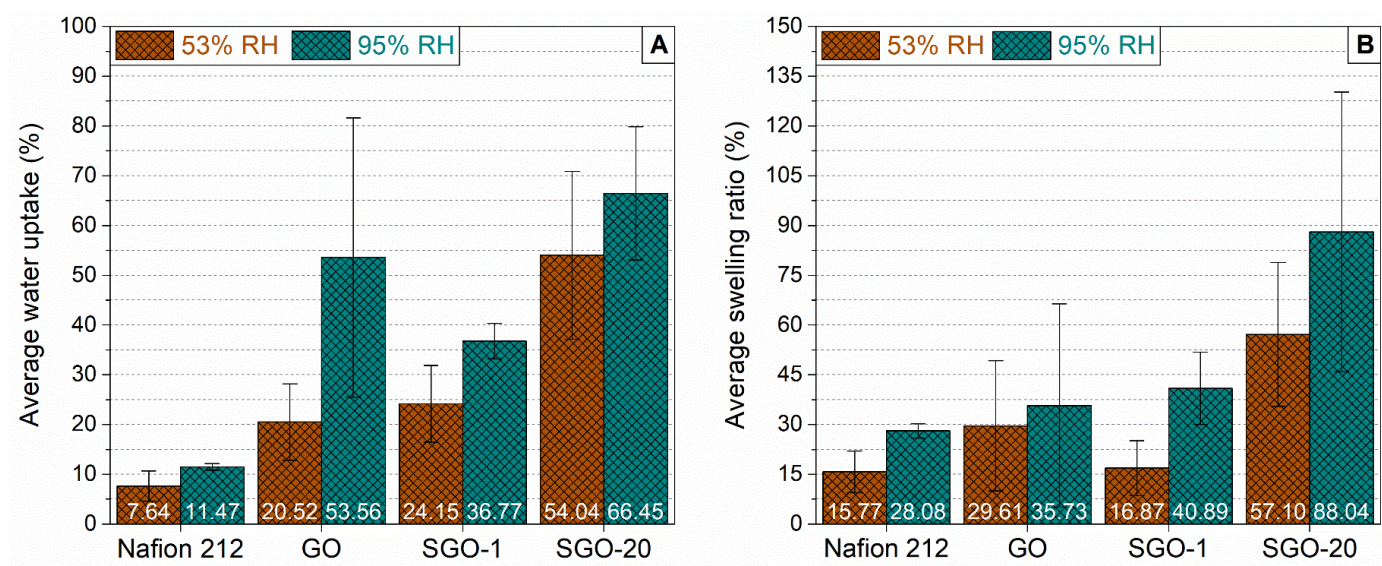

Figure 7. (A) Average WU and (B) Average SR calculated for Nafion ${ }^{\circledR} 212$ and GO-based membranes by averaging the results of each specimen with respect to all temperatures at fixed RH.

Moving to GO, it can be observed that the water uptake at 95\% RH is much higher than the one of Nafion 212 (Figure $6 \mathrm{~B})$; in particular, it exhibits an average value of $72.39 \pm 15.48 \%$ below $80{ }^{\circ} \mathrm{C}$. In the same range, the swelling ratio (Figure 6D) turns out lower than that of $\mathrm{Nafion}^{\circledR} 212(15.97 \pm 6.73 \%$ versus $28.08 \pm 2.19 \%)$, suggesting an overall better behavior of GO. Nevertheless, above $80{ }^{\circ} \mathrm{C}$ the water uptake drops to values that are still larger than those of Nafion ${ }^{\circledR}$ 212 while the swelling ratio increases significantly up to $80 \%$; this is probably a sign of the fact that GO suffers a thermally induced degradation.

If the relative humidity is reduced to $53 \%$, it is evident the enhancement in the water sorption ability of GO as against the one of Nafion ${ }^{\circledR} 212$, with an average value of $20.52 \pm 7.69 \%$ versus $7.64 \pm 3.06 \%$, respectively (Figure 7A); moreover, the swelling ratio remains more moderate than at $95 \% \mathrm{RH}$ and rises only at elevated temperatures, indicating a better dimensional stability (Figure 7B). Thus, the low-temperature water uptake behavior of GO changes significantly with the degree of humidification. This can be explained by considering a mechanism proposed by Liu et al. [58]. At low relative humidity, water molecules are mostly adsorbed on the surface of the membrane and penetrate slowly into GO layers; consequently, when the samples are dried with paper before measuring the wet weight, most of the adsorbed water is removed. On the other hand, at higher humidification, the component is quickly soaked by water vapor and a multilayer adsorption takes place, leading to an improvement in the average interlayer distance and in the frailty of the material. When sulfonic acid groups are introduced on the framework of GO, the behavior looks more uniform at all temperatures and the higher is the acid-to-GO molar ratio the larger is the water uptake; unfortunately, the swelling ratio rises as well, which may be detrimental for the durability of the membrane if subjected to repeated wetting/drying cycles. In the case of SGO-1, the average low-humidity behavior is enhanced as opposed to GO, as depicted in Figures 6A,C and 7, since its water uptake is larger while its swelling ratio is smaller, mainly at high temperatures. By rising the sulfonation ratio to 20, the corresponding component exhibits a strong increase in the water sorption ability, especially at 53\% RH (Figure $6 \mathrm{~A}$ ); this can be ascribed to the hydrophilic action of $-\mathrm{SO}_{3} \mathrm{H}$ groups. However, SGO-20's water uptake seems to suffer a slight drop above $60{ }^{\circ} \mathrm{C}$, indicating a slight instability. Another possible issue is its large swelling ratio, which doubles (on average) as against both GO and SGO-1 (Figure 7B). 


\subsection{Ion exchange capacity and proton conductivity}

Along with water uptake, the ion exchange capacity is another essential parameter to be assessed for a potential protonconducting membrane, because it gives an estimate of its ability to carry $\mathrm{H}^{+}$ions. Hence, in combination with the degree of sulfonation, it allows to assess the role of the sulfonic functionalities of SGO-X and Nafion ${ }^{\circledR} 212$ specimens on the mechanism of ionic conduction. The corresponding results are illustrated in Figure 8.
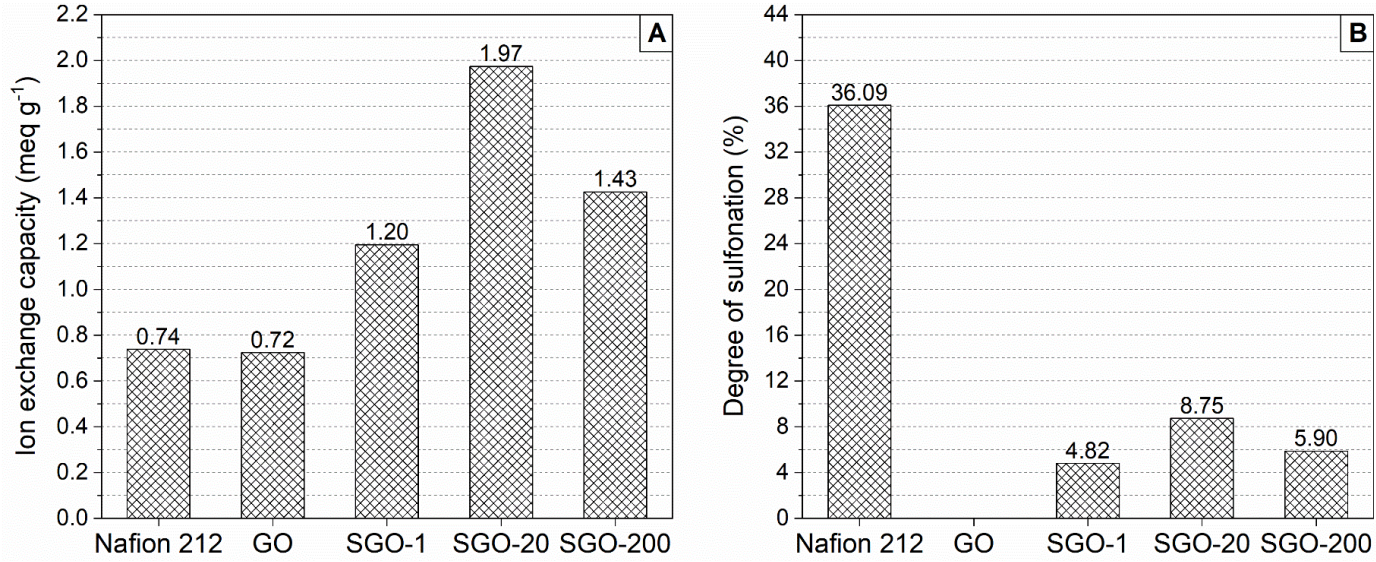

Figure 8. (A) Ion exchange capacity and (B) Degree of sulfonation values of Nafion ${ }^{\circledR} 212$, GO and SGO-X membranes.

A value of $0.74 \mathrm{meq}^{-1}$ has been measured for Nafion ${ }^{\circledR} 212$, which is slightly smaller than determinations reported in literature, about $0.90 \mathrm{meq}^{-1}$ [16,59]; this can be a consequence of the drying step performed before the actual experiment, which may have damaged the most superficial $-\mathrm{SO}_{3} \mathrm{H}$ moieties. A similar result $\left(0.72 \mathrm{meq}^{-1}\right)$ has been exhibited by pristine GO, fairly in agreement with the one evaluated by Jiang et al. [22], considering that its ion exchange capacity is strongly influenced by the preparation method, which determines its degree of oxidation, and by its arrangement in the form of powders or of a membrane [22,36].

Moving to sulfonated specimens, even the lowest acid-to-GO molar ratio displays a significant increase in the protonconducting ability as opposed to both $\mathrm{Nafion}^{\circledR} 212$ and virgin $\mathrm{GO}$, since a value of $1.20 \mathrm{meq} \mathrm{g}^{-1}$ has been obtained (Figure $8 \mathrm{~A})$, in agreement with those reported in literature [16,22,23]. A remarkable finding is that SGO-20 $\left(1.97 \mathrm{meq} \mathrm{g}^{-1}\right)$ appears to provide better features than SGO-200 (1.43 meq $\left.\mathrm{g}^{-1}\right)$ even though it has been prepared with a lower sulfonation ratio. This suggests that the functionalization process may be more efficient with an acid-to-GO ratio within the 1-20 range, and it seems useless to employ a higher sulfuric acid content, given that even the SGO-20 membrane has troubles in selfassembling.

Considering the previous results and the lack of self-assembling properties, SGO-200 samples have not been tested for the ex-situ determination of their proton conductivity. For this purpose, the analysis of the other components has been limited only to the medium-high frequency arcs of the Nyquist plots, an example of which is displayed in Figure 9, neglecting low-frequency contributions when present. In fact, the former can be attributed to the membrane's behavior, the arc diameter being the internal resistance $\left(\mathrm{R}_{\mathrm{i}}\right)$, which can be correlated to ionic transfer processes and to the material's proton conductivity. The latter, instead, mostly correspond to mass transport limitations at the electrode/electrolyte interface, which is much thinner than the membrane itself, thus producing a higher time constant, from which the shift to lower frequencies $[19,60]$. 


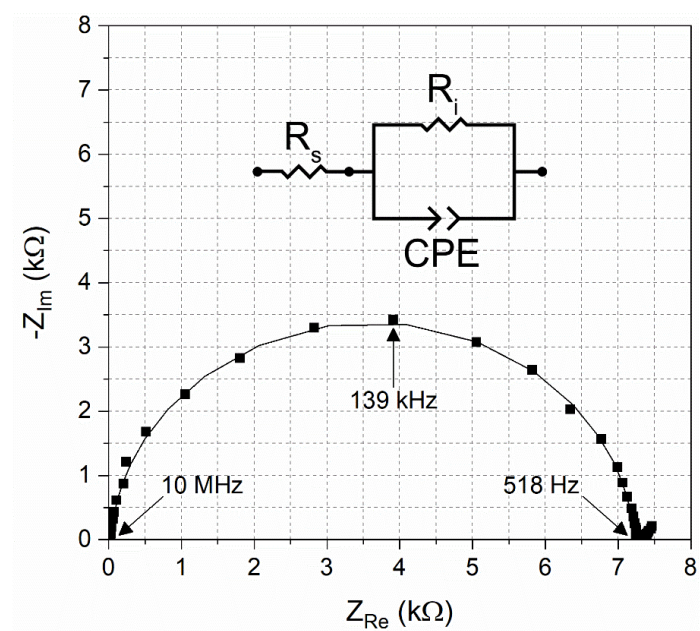

Figure 9. Experimental data ( $\mathbf{\square})$ and fitting curve (-) for a sample of GO, tested at $80{ }^{\circ} \mathrm{C}$ and $53 \%$ RH. The inset contains the equivalent circuit used to fit the experimental Nyquist plot.

Therefore, the Randles cell model has been employed to fit the medium-high frequency semicircle, even if it has been modified by replacing the ideal capacitor with a constant phase element (CPE), in order to account for the inherent porosity and roughness of the electrode/membrane interface, responsible for depressed semicircles [61,62]. As shown in Figure 9, the CPE is in parallel to $\mathrm{R}_{\mathrm{i}}$, and the whole $\mathrm{RC}$ element is in series with $\mathrm{R}_{\mathrm{s}}$, the high-frequency intercept of the arc on the real impedance $\left(Z_{\mathrm{Re}}\right)$ axis, accounting for ohmic losses in the system [60,63]. The proton conductivity values extracted from the Nyquist diagrams of all analyzed membranes are summarized in Table 1 and plotted in Figure 10.

Table 1. Proton conductivity $(\sigma)$ values of GO-based and $\mathrm{Nafion}^{\circledR} 212$ membranes, reported as a function of temperature and relative humidity (RH).

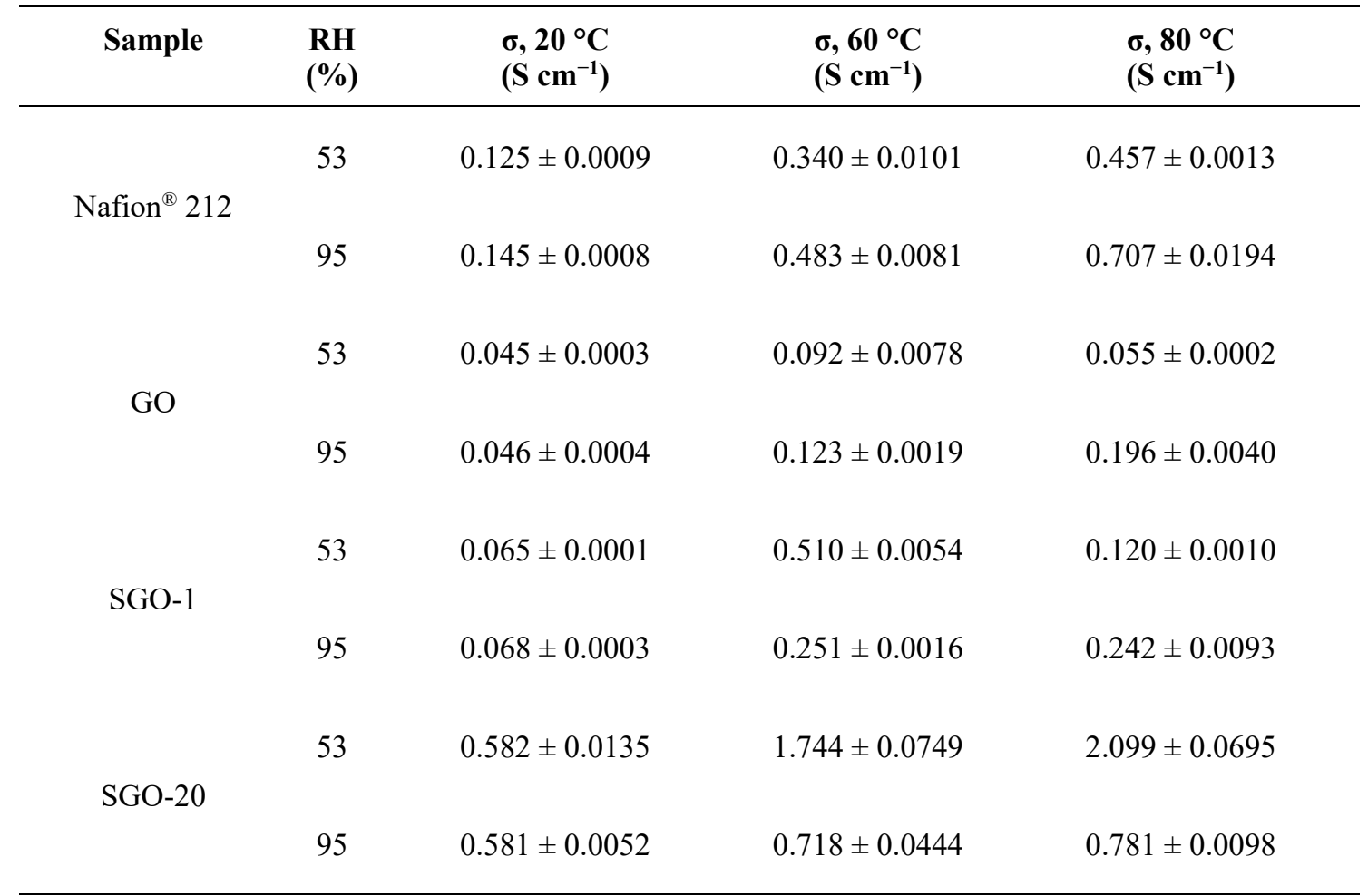



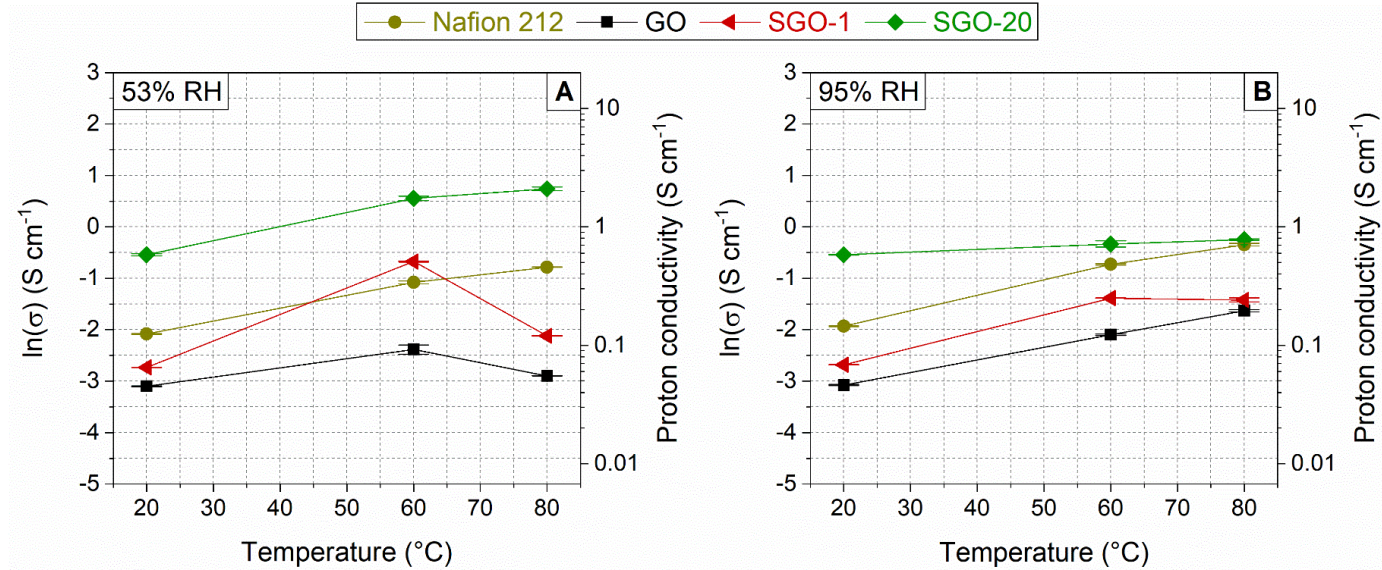

Figure 10. Temperature dependence of the proton conductivity of Nafion ${ }^{\circledR} 212$, GO and SGO-X membranes, plotted between 20 and $80{ }^{\circ} \mathrm{C}$, at (A) $53 \% \mathrm{RH}$ and (B) $95 \% \mathrm{RH}$.

As expected, the proton conductivity of Nafion $^{\circledR} 212$ increases both with temperature and relative humidity, from 0.125 $\pm 0.0009 \mathrm{~S} \mathrm{~cm}^{-1}$ at $20{ }^{\circ} \mathrm{C}, 53 \% \mathrm{RH}$ to $0.707 \pm 0.0194 \mathrm{~S} \mathrm{~cm}^{-1}$ at $80{ }^{\circ} \mathrm{C}, 95 \% \mathrm{RH}$. These values are somewhat higher than the typical ones reported in literature, even if in the same range $\left(10^{-1} \mathrm{~S} \mathrm{~cm}^{-1}\right)[25,27]$. A plausible explanation lies in the condensation of some water droplets on the surface of the metallic electrodes, especially at higher temperatures, which might have slightly tampered with the measurements. Nevertheless, these conditions were the same for all membranes and the resulting trends should still be significant.

Virgin GO exhibits a worse behavior, particularly at 53\% RH (Figure 10A), since its conductivity drops from $0.092 \pm$ $0.0078 \mathrm{~S} \mathrm{~cm}^{-1}$ at $60{ }^{\circ} \mathrm{C}$ to $0.055 \pm 0.0002 \mathrm{~S} \mathrm{~cm}^{-1}$ at $80^{\circ} \mathrm{C}$, denoting a low thermal stability of the material, as reported in previous works [17,19] and witnessed in water uptake tests. It is interesting to note the discrepancy between conductivity and ion exchange capacity values of GO and Nafion ${ }^{\circledR} 212$, suggesting that the proton transport mechanism of GO involves less oxygen-bearing functionalities than those actually able to exchange $\mathrm{H}^{+}$ions in the conditions of an IEC test.

The sulfonation process appears to enhance the proton conductivity of GO, in agreement with previous literature [22], and the results of SGO-X membranes rise with the acid-to-GO molar ratio at all analyzed temperatures and humidities. SGO-1 displays a behavior similar to that of GO, since its conductivity decreases above $60{ }^{\circ} \mathrm{C}$ at both $53 \%$ and $95 \% \mathrm{RH}$, even though being still above $0.1 \mathrm{~S} \mathrm{~cm}^{-1}$ and closer to the one of Nafion ${ }^{\circledR} 212$. This outcome indicates that the sulfonation degree of SGO-1 is probably too mild for a significant conductivity improvement, which instead seems to be achieved in the case of SGO-20. Its values are consistently greater than those of Nafion ${ }^{\circledR} 212$, with a remarkable behavior at reduced humidity (Figure 10A). However, despite the excellent proton conductivity, SGO-20 cannot be taken into account for forthcoming practical applications, due to the self-assembling issues witnessed during its preparation. These findings seem to confirm the potentiality of the proposed SGO-X membranes as a possible novel electrolyte for PEMFCs, even if further investigations should focus their attention on identifying an ideal sulfonation ratio in the 1-20 range, in order to achieve an efficient compromise between self-assembling properties, structural stability and proton-carrying ability.

\section{Conclusions}

This experimental work has described the development of a simple and effective method for the production of selfassembling GO-based membranes functionalized with sulfonic acid groups. Three different sulfuric acid-to-GO molar 
ratios have been investigated, evaluating their impact on both structure and properties of SGO-X layers by means of an extensive morphological and functional characterization.

ATR-FTIR and EDX spectroscopies, coupled with thermogravimetry, allowed to verify the efficacy of the sulfonation reaction. Nevertheless, a potential side effect of the functionalization process may be a partial reduction of the basal plane of $\mathrm{GO}$, since the incorporation of $-\mathrm{SO}_{3} \mathrm{H}$ moieties appears to take place at the expense of oxygen-containing ones, as hinted by the analysis of infrared spectra. This outcome is already visible at the lowest sulfonation ratio $(\mathrm{X}=1)$ and should be addressed in future developments of these components. The rise in the acid-to-GO molar ratio seems to enhance the reduction effect but also to ensure the formation of more stable bonds among sulfonic acid functions and GO, as suggested by thermogravimetric plots. However, an excessive concentration is probably responsible for the disruption of the self-assembling ability of the material, reducing its thermal stability and hindering the formation of a compact film, as witnessed specifically in SGO-200 specimens, which have been thereby excluded from a more in-depth examination. SGO-X membranes have shown encouraging water uptake and ion exchange behaviors. In particular, the former resulted to be increased in conditions of reduced humidity, which are most suffered by Nafion ${ }^{\circledR}$, even though sulfonated samples exhibited a lower structural consistency. Then, the best ion exchange capacity ( $\left.1.97 \mathrm{meq}^{-1}\right)$ has been attained by SGO20 , more than twice the one recorded for virgin GO and Nafion ${ }^{\circledR} 212$. The proton conductivity appears to be enhanced as well by the sulfonation reaction, especially at 53\% RH, with SGO-1 showing values better than those of GO, while the behavior of SGO-20 is improved also with respect to Nafion ${ }^{\circledR} 212$.

All things considered, the proposed membranes have shown promising functional properties as against both bare GO and Nafion ${ }^{\circledR} 212$, making them an interesting candidate for future trials in PEM fuel cells working at reduced humidification, while their high-temperature behavior is yet to be enhanced. However, before an actual test can be carried out, an optimal sulfonation ratio should still be detected in the range between $X=1$ and $X=20$; further investigations are also required so as to optimize the functionalization process and to achieve a perfect assembling of the material, minimizing the removal of oxygenated groups. Moreover, appropriate strategies should be developed for the reinforcement of the component's structure and of its bonds with the introduced sulfonic acid moieties, perhaps by exploiting some mild crosslinking agents, in order to achieve a sufficient mechanical stability for a successful operation in PEMFCs.

Funding: This research did not receive any specific grant from funding agencies in the public, commercial, or not-for-profit sectors. Acknowledgments: The authors wish to thank Dr. Luigi Brambilla and the FuNMat (Organic Functional and Nanostructured Materials) laboratory of the Department of Chemistry, Materials and Chemical Engineering "Giulio Natta" at Politecnico di Milano, for their help and expertise in the acquisition and interpretation of infrared spectra.

\section{References}

[1] Vinoth S, Kanimozhi G, Narsimulu D, Kumar H, Srinadhu ES, Satyanarayana N. Ionic relaxation of electrospun nanocomposite polymer-blend quasi-solid electrolyte for high photovoltaic performance of Dyesensitized solar cells. Mater Chem Phys 2020;250:122945. https://doi.org/10.1016/j.matchemphys.2020.122945.

[2] Kim Y-J, Ahn CH, Lee MB, Choi M-S. Characteristics of electrospun PVDF/SiO2 composite nanofiber membranes as polymer electrolyte. Mater Chem Phys 2011;127:137-42. https://doi.org/10.1016/j.matchemphys.2011.01.046.

[3] Arifeen WU, Kim M, Ting D, Kurniawan R, Choi J, Yoo K, et al. Hybrid thermal resistant electrospun polymer membrane as the separator of lithium ion batteries. Mater Chem Phys 2020;245:122780. 
https://doi.org/10.1016/j.matchemphys.2020.122780.

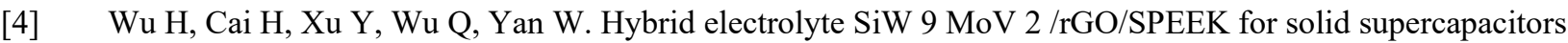
with enhanced conductive performance. Mater Chem Phys 2018;215:163-7. https://doi.org/10.1016/j.matchemphys.2018.05.020.

[5] Castro Y, Mosa J, Aparicio M, Pérez-Carrillo LA, Vílchez S, Esquena J, et al. Sol-gel hybrid membranes loaded with meso/macroporous $\mathrm{SiO} 2, \mathrm{TiO} 2-\mathrm{P} 2 \mathrm{O} 5$ and $\mathrm{SiO} 2-\mathrm{TiO} 2-\mathrm{P} 2 \mathrm{O} 5$ materials with high proton conductivity. Mater Chem Phys 2015;149-150:686-94. https://doi.org/10.1016/j.matchemphys.2014.11.028.

[6] Mandal AK, Bera D, Banerjee S. Sulfonated polyimides containing triphenylphosphine oxide for proton exchange membranes. Mater Chem Phys 2016;181:265-76. https://doi.org/10.1016/j.matchemphys.2016.06.058.

[7] United Nations - Department of Economic and Social Affairs (Population Division). World population prospects 2019: highlights. New York, NY (US): United Nations; 2019. https://population.un.org/wpp/Publications/Files/WPP2019_Highlights.pdf (accessed March 24, 2020).

[8] International Energy Agency. World energy outlook 2018. Paris (FR): IEA Publications; 2018. https://doi.org/10.1787/weo-2018-en.

[9] Fuel Cells and Hydrogen Joint Undertaking. Fuel cell and hydrogen technology: Europe's journey to a greener world. Herstal (BE): Publications office of the European Union; 2017. https://doi.org/10.2843/875050.

[10] Barbir F. Introduction. PEM Fuel Cells. 2nd ed., Amsterdam (NL): Academic Press; 2013, p. 1-16. https://doi.org/10.1016/B978-0-12-387710-9.00001-1.

[11] Wang Y, Chen KS, Mishler J, Cho SC, Adroher XC. A review of polymer electrolyte membrane fuel cells: technology, applications, and needs on fundamental research. Appl Energy 2011;88:981-1007. https://doi.org/10.1016/j.apenergy.2010.09.030.

[12] Houchins C, Kleen G, Spendelow J, Kopasz J, Peterson D, Garland N, et al. U.S. DOE progress towards developing low-cost, high performance, durable polymer electrolyte membranes for fuel cell applications. Membranes (Basel) 2012;2:855-78. https://doi.org/10.3390/membranes2040855.

[13] Barbir F. Main cell components, material properties, and processes. PEM Fuel Cells. 2nd ed., Amsterdam (NL): Academic Press; 2013, p. 73-117. https://doi.org/10.1016/B978-0-12-387710-9.00004-7.

[14] Satterfield MB, Majsztrik PW, Ota H, Benziger JB, Bocarsly AB. Mechanical properties of Nafion and titania/Nafion composite membranes for polymer electrolyte membrane fuel cells. J Polym Sci Part B Polym Phys 2006;44:2327-45. https://doi.org/10.1002/polb.20857.

[15] Francia C, Ijeri VS, Specchia S, Spinelli P. Estimation of hydrogen crossover through Nafion membranes in PEMFCs. J Power Sources 2011;196:1833-9. https://doi.org/10.1016/j.jpowsour.2010.09.058.

[16] Kumar R, Scott K. Freestanding sulfonated graphene oxide paper: a new polymer electrolyte for polymer electrolyte fuel cells. Chem Commun 2012;48:5584-6. https://doi.org/10.1039/c2cc31771k.

[17] Bayer T, Selyanchyn R, Fujikawa S, Sasaki K, Lyth SM. Spray-painted graphene oxide membrane fuel cells. J Memb Sci 2017;541:347-57. https://doi.org/10.1016/j.memsci.2017.07.012.

[18] Nafion perfluorinated membrane NRE-212, Sigma-Aldrich 2020. https://www.sigmaaldrich.com/catalog/product/aldrich/676470?lang=it\&region=IT (accessed March 24, 2020).

[19] Bayer T, Bishop SR, Nishihara M, Sasaki K, Lyth SM. Characterization of a graphene oxide membrane fuel cell. J Power Sources 2014;272:239-47. https://doi.org/10.1016/j.jpowsour.2014.08.071.

[20] Quartarone E, Angioni S, Mustarelli P. Polymer and composite membranes for proton-conducting, high- 
temperature fuel cells: a critical review. Materials (Basel) 2017;10:687. https://doi.org/10.3390/ma10070687.

[21] Sun X, Simonsen SC, Norby T, Chatzitakis A. Composite membranes for high temperature PEM fuel cells and electrolysers: a critical review. Membranes (Basel) 2019;9:83. https://doi.org/10.3390/membranes9070083.

[22] Jiang Z, Shi Y, Jiang ZJ, Tian X, Luo L, Chen W. High performance of a free-standing sulfonic acid functionalized holey graphene oxide paper as a proton conducting polymer electrolyte for air-breathing direct methanol fuel cells. J Mater Chem A 2014;2:6494-503. https://doi.org/10.1039/c4ta00208c.

[23] Sandström R, Annamalai A, Boulanger N, Ekspong J, Talyzin A, Mühlbacher I, et al. Evaluation of fluorine and sulfonic acid co-functionalized graphene oxide membranes under hydrogen proton exchange membrane fuel cell conditions. Sustain Energy Fuels 2019;3:1790-8. https://doi.org/10.1039/C9SE00126C.

[24] Zarrin H, Higgins D, Jun Y, Chen Z, Fowler M. Functionalized graphene oxide nanocomposite membrane for low humidity and high temperature proton exchange membrane fuel cells. J Phys Chem C 2011;115:20774-81. https://doi.org/10.1021/jp204610j.

[25] Chien HC, Tsai LD, Huang CP, Kang CY, Lin JN, Chang FC. Sulfonated graphene oxide/Nafion composite membranes for high-performance direct methanol fuel cells. Int J Hydrogen Energy 2013;38:13792-801. https://doi.org/10.1016/j.ijhydene.2013.08.036.

[26] Lee DC, Yang HN, Park SH, Kim WJ. Nafion/graphene oxide composite membranes for low humidifying polymer electrolyte membrane fuel cell. J Memb Sci 2014;452:20-8. https://doi.org/10.1016/j.memsci.2013.10.018.

[27] Peng KJ, Lai JY, Liu YL. Nanohybrids of graphene oxide chemically-bonded with Nafion: preparation and application for proton exchange membrane fuel cells. J Memb Sci 2016;514:86-94. https://doi.org/10.1016/j.memsci.2016.04.062.

[28] Vinothkannan M, Kim AR, Gnana Kumar G, Yoo DJ. Sulfonated graphene oxide/Nafion composite membranes for high temperature and low humidity proton exchange membrane fuel cells. RSC Adv 2018;8:7494-508. https://doi.org/10.1039/c7ra12768e.

[29] Ibrahim A, Hossain O, Chaggar J, Steinberger-Wilckens R, El-Kharouf A. GO-nafion composite membrane development for enabling intermediate temperature operation of polymer electrolyte fuel cell. Int J Hydrogen Energy 2020;45:5526-34. https://doi.org/10.1016/j.ijhydene.2019.05.210.

[30] He Y, Wang J, Zhang H, Zhang T, Zhang B, Cao S, et al. Polydopamine-modified graphene oxide nanocomposite membrane for proton exchange membrane fuel cell under anhydrous conditions. J Mater Chem A 2014;2:9548-58. https://doi.org/10.1039/c3ta15301k.

[31] Pandey RP, Thakur AK, Shahi VK. Sulfonated polyimide/acid-functionalized graphene oxide composite polymer electrolyte membranes with improved proton conductivity and water-retention properties. ACS Appl Mater Interfaces 2014;6:16993-7002. https://doi.org/10.1021/am504597a.

[32] Pandey RP, Shahi VK. Sulphonated imidized graphene oxide (SIGO) based polymer electrolyte membrane for improved water retention, stability and proton conductivity. J Power Sources 2015;299:104-13. https://doi.org/10.1016/j.jpowsour.2015.08.093.

[33] Gahlot S, Sharma PP, Kulshrestha V, Jha PK. SGO/SPES-based highly conducting polymer electrolyte membranes for fuel cell application. ACS Appl Mater Interfaces 2014;6:5595-601. https://doi.org/10.1021/am5000504.

[34] Zhao Y, Fu Y, He Y, Hu B, Liu L, Lü J, et al. Enhanced performance of poly(ether sulfone) based composite proton exchange membranes with sulfonated polymer brush functionalized graphene oxide. RSC Adv 
2015;5:93480-90. https://doi.org/10.1039/C5RA17915G.

[35] Miao S, Zhang H, Li X, Wu Y. A morphology and property study of composite membranes based on sulfonated polyarylene ether sulfone and adequately sulfonated graphene oxide. Int J Hydrogen Energy 2016;41:331-41. https://doi.org/10.1016/j.ijhydene.2015.10.080.

[36] Vinothkannan M, Kannan R, Kim AR, Kumar GG, Nahm KS, Yoo DJ. Facile enhancement in proton conductivity of sulfonated poly (ether ether ketone) using functionalized graphene oxide - Synthesis, characterization, and application towards proton exchange membrane fuel cells. Colloid Polym Sci 2016;294:1197-207. https://doi.org/10.1007/s00396-016-3877-8.

[37] Jiang ZJ, Jiang Z, Tian X, Luo L, Liu M. Sulfonated holey graphene oxide (SHGO) filled sulfonated poly(ether ether ketone) membrane: the role of holes in the SHGO in improving its performance as proton exchange membrane for direct methanol fuel cells. ACS Appl Mater Interfaces 2017;9:20046-56. https://doi.org/10.1021/acsami.7b00198.

[38] Jang H-R, Yoo E-S, Kannan R, Kim J-S, Lee K, Yoo DJ. Facile tailor-made enhancement in proton conductivity of sulfonated poly(ether ether ketone) by graphene oxide nanosheet for polymer electrolyte membrane fuel cell applications. Colloid Polym Sci 2017;295:1059-69. https://doi.org/10.1007/s00396-0174095-8.

[39] Dikin DA, Stankovich S, Zimney EJ, Piner RD, Dommett GHB, Evmenenko G, et al. Preparation and characterization of graphene oxide paper. Nature 2007;448:457-60. https://doi.org/10.1038/nature06016.

[40] Dreyer DR, Park S, Bielawski CW, Ruoff RS. The chemistry of graphene oxide. Chem Soc Rev 2010;39:22840. https://doi.org/https://doi.org/10.1039/B917103G.

[41] Farooqui UR, Ahmad AL, Hamid NA. Graphene oxide: a promising membrane material for fuel cells. Renew Sustain Energy Rev 2018;82:714-33. https://doi.org/10.1016/j.rser.2017.09.081.

[42] Latorrata S, Basso Peressut A, Gallo Stampino P, Cristiani C, Dotelli G. Preliminary study on the development of sulfonated graphene oxide membranes as potential novel electrolytes for PEM fuel cells. ECS Trans 2018;86:347-56. https://doi.org/10.1149/08613.0347ecst.

[43] Cheng T, Feng M, Huang Y, Liu X. SGO/SPEN-based highly selective polymer electrolyte membranes for direct methanol fuel cells. Ionics (Kiel) 2017;23:2143-52. https://oi.org/10.1007/s11581-017-2057-2.

[44] Xu Q, Wang L, Li C, Wang X, Li C, Geng Y. Study on improvement of the proton conductivity and antifouling of proton exchange membrane by doping SGO@SiO2 in microbial fuel cell applications. Int J Hydrogen Energy 2019;44:15322-32. https://doi.org/10.1016/j.ijhydene.2019.03.238.

[45] Graphene oxide, product datasheet 2017. https://cdn.shopify.com/s/files/1/0191/2296/files/Graphenea_GO_4mgmL_Datasheet_201709.pdf?5800692833 297688208 (accessed March 24, 2020).

[46] Dotelli G, Gallazzi MC, Mari CM, Greppi F, Montoneri E, Manuelli A. Polyalkylphosphazenes as solid proton conducting electrolytes. J Mater Sci 2004;39:6937-43. https://doi.org/10.1023/B:JMSC.0000047535.62034.60.

[47] Kumari M, Sodaye HS, Bindal RC. Cross-linked sulfonated poly(ether ether ketone)-poly ethylene glycol/silica organic-inorganic nanocomposite membrane for fuel cell application. J Power Sources 2018;398:137-48. https://doi.org/10.1016/j.jpowsour.2018.07.053.

[48] Liu J, Xue Y, Dai L. Sulfated graphene oxide as a hole-extraction layer in high-performance polymer solar cells. J Phys Chem Lett 2012;3:1928-33. https://doi.org/10.1021/jz300723h.

[49] Iwan A, Caballero-Briones F, Malinowski M, Filapek M, Tazbir I, Guerrero-Contreras J, et al. Graphene oxide 
[50] Acik M, Mattevi C, Gong C, Lee G, Cho K, Chhowalla M, et al. The role of intercalated water in multilayered graphene oxide. ACS Nano 2010;4:5861-8. https://doi.org/10.1021/nn101844t.

[51] Eluyemi MS, Ayinde SA, Eleruja MA, Fasakin O, Olofinjana B, Ilori OO, et al. Synthesis and characterization of graphene oxide and reduced graphene oxide thin films deposited by spray pyrolysis method. Graphene 2016;05:143-54. https://doi.org/10.4236/graphene.2016.53012.

[52] Kang Y, Obaid M, Jang J, Ham MH, Kim IS. Novel sulfonated graphene oxide incorporated polysulfone nanocomposite membranes for enhanced-performance in ultrafiltration process. Chemosphere 2018;207:581-9. https://doi.org/10.1016/j.chemosphere.2018.05.141.

[53] Larkin P. General outline and strategies for IR and Raman spectral interpretation. Infrared Raman Spectrosc. 1st ed., Waltham, MA (US): Elsevier; 2011, p. 117-33. https://doi.org/10.1016/B978-0-12-386984-5.10007-2.

[54] Larkin P. IR and Raman spectra-structure correlations. Infrared Raman Spectrosc. 1st ed., Waltham, MA (US): Elsevier; 2011, p. 73-115. https://doi.org/10.1016/B978-0-12-386984-5.10006-0.

[55] de Almeida SH, Kawano Y. Thermal behavior of Nafion membrane. J Therm Anal Calorim 1999;58:569-77. https://doi.org/10.1023/A:1010196226309.

[56] Law K-Y, Zhao H. Wetting on rough surfaces. Surf. Wetting, Cham: Springer International Publishing; 2016 , p. 55-98. https://doi.org/10.1007/978-3-319-25214-8_4.

[57] Shi S, Weber AZ, Kusoglu A. Structure/property relationship of Nafion XL composite membranes. J Memb Sci 2016;516:123-34. https://doi.org/10.1016/j.memsci.2016.06.004.

[58] Liu R, Gong T, Zhang K, Lee C. Graphene oxide papers with high water adsorption capacity for air dehumidification. Sci Rep 2017;7:9761. https://doi.org/10.1038/s41598-017-09777-y.

[59] Dai H, Zhang H, Luo Q, Zhang Y, Bi C. Properties and fuel cell performance of proton exchange membranes prepared from disulfonated poly(sulfide sulfone). J Power Sources 2008;185:19-25. https://doi.org/10.1016/j.jpowsour.2008.07.012.

[60] Yuan X-Z, Song C, Wang H, Zhang J. Electrical Fundamentals. Electrochem. Impedance Spectrosc. PEM Fuel Cells, London (UK): Springer London; 2010, p. 39-93. https://doi.org/10.1007/978-1-84882-846-9 2.

[61] Yuan X-Z, Song C, Wang H, Zhang J. EIS equivalent circuits. Electrochem. Impedance Spectrosc. PEM Fuel Cells, London (UK): Springer London; 2010, p. 139-92. https://doi.org/10.1007/978-1-84882-846-9_4.

[62] Rezaei Niya SM, Hoorfar M. Study of proton exchange membrane fuel cells using electrochemical impedance spectroscopy technique - A review. J Power Sources 2013;240:281-93. https://doi.org/10.1016/j.jpowsour.2013.04.011.

[63] Yuan X-Z, Song C, Wang H, Zhang J. Impedance and its corresponding electrochemical processes. Electrochem. Impedance Spectrosc. PEM Fuel Cells, London (UK): Springer London; 2010, p. 95-138. https://doi.org/10.1007/978-1-84882-846-9_3. 
Electronic Supplementary Material
Click here to download Electronic Supplementary Material: Basso Peressut et al_Supplementary information.docx 


\section{Declaration of interests}

$\bigotimes$ The authors declare that they have no known competing financial interests or personal relationships that could have appeared to influence the work reported in this paper.

$\square$ The authors declare the following financial interests/personal relationships which may be considered as potential competing interests:
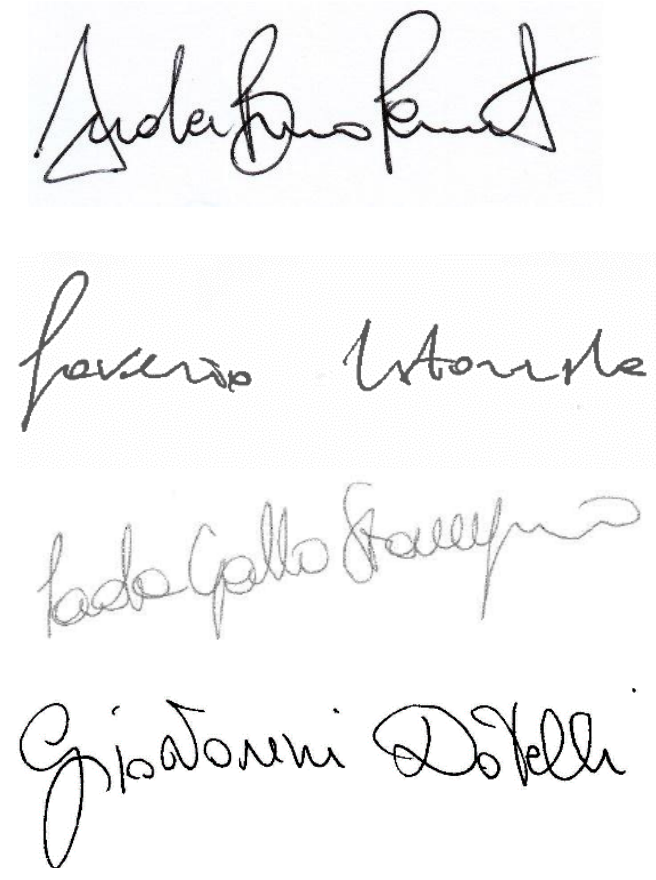